\title{
Investigating International Strategic Brand Management and Export Performance Outcomes in the B2B context
}

Authors: Pyper, K., Doherty, A.M., Gounaris, S. and Wilson, A.

Journal: International Marketing Review

Date Accepted: 17 October 2019

DOI (10.1108/IMR-02-2019-0087)

Licensing Statement: This paper is deposited with permission from Emerald under the Creative Commons Attribution Non-commercial International Licence 4.0 (CC BY-NC 4.0). To reuse the AAM for commercial purposes, permission should be sought by contacting permissions@emeraldinsight.com 


\title{
Investigating International Strategic Brand Management and Export \\ Performance Outcomes in the B2B context
}

\begin{abstract}
- Purpose - Drawing on Resource Based Theory, the purpose of this paper is to empirically examine the effect of International Strategic Brand Management on export performance within the Business to Business (B2B) context. To be able to purposely assess the relationship this paper also sets out to discover what antecedent international resources, (financial resources), and international capabilities (market information, branding, marketing planning) contribute to the ability of B2B exporters to effectively manage their brands abroad.
\end{abstract}

- Design/methodology/approach - A mixed method firm level approach was employed. First a qualitative study of 34 in-depth interviews explored the focal inter-relationships and constructs identified within the literature. A survey of 208 successful UK exporters was then conducted and the results were analysed using structural equation modeling.

- Findings - The results confirm certain international marketing capabilities (branding and marketing planning) are advantageous antecedents to the employment of effective strategic brand management in foreign markets which, in turn, leads to increased financial and market performance internationally.

- Practical implications - This paper outlines practical brand management considerations managers need to account for to achieve effective exporting. Practitioners are advised to prioritise the development of robust international branding and marketing planning capabilities which can enable them to exploit their limited financial resources for optimal benefits. Further, by developing these capabilities firms' can focus on the essence of their brand and communicate their brand image through the effective strategic management of their brand to business customers evoking positive brand associations, enhanced perceived brand value and the achievement of increased export performance.

- Originality/value - This paper is the first to focus on international strategic brand management as the deterministic factor leading to improved B2B export performance. An innovative framework is offered which positions the pivotal role of International Strategic Brand Management as the central focus. The construct for international branding capabilities is extended specifically for use in the B2B domain.

- Keywords - B2B Brands, Strategic Brand Management, Resource Based Theory, International Marketing, Export Performance.

- Paper Type - Research Paper 


\section{Introduction}

There has been a swell of academic enquiry into Business to Business (B2B) branding over the past two decades (Seyedghorban et al., 2016). This corresponds with the growing recognition that B2B brands play a pivotal role in the contemporary global market (Wang and Hao, 2018), and that the economic value of B2B transactions equals that of Business to Consumer (B2C) transactions (Lilien, 2016). The upsurge in studies has also been ignited by a growing realisation that results from previous investigations conducted in a $\mathrm{B} 2 \mathrm{C}$ context cannot be relied upon when applied in a $\mathrm{B} 2 \mathrm{~B}$ domain due to the fundamental differences in $\mathrm{B} 2 \mathrm{~B}$ and $\mathrm{B} 2 \mathrm{C}$ markets (Mudambi, 2002; Zablah et al., 2010; Glynn, 2012; Lilien and Grewal, 2012; Wiersema, 2013; Lilien, 2016; Dotzel and Shankar, 2019; Swani et al., 2019). Given that consumer branding does not address the B2B context (Glynn and Woodside, 2009) and that studies have demonstrated that B2B and B2C marketing is unequivocally different (e.g. Iankova et al., 2018; Dotzel and Shankar, 2019). the development and validation of B2B frameworks is a particular concern (Coleman et al. 2011). Significant differences are especially apparent when comparing $\mathrm{B} 2 \mathrm{C}$ and $\mathrm{B} 2 \mathrm{~B}$ brand management. For example, B2B brand management takes place at the corporate level not the product level, involves fewer brands and places much greater emphasis on risk reduction over the self-expressive benefits of brands (Mudambi, 2002; Rosenbaum-Elliott et al., 2011; Kapferer, 2012; Keller, 2013). Despite the growth in B2B branding studies, disparities still exist within certain domains of branding research. The vast majority of scholars investigating strategic brand management (hereafter referred to as SBM) outcomes have continued to focus on the consumer perspective; however, it is equally important for success in the B2B context (Kotler and Pfoertsch, 2007).

Brand management is a method for expediting the achievement of a brand's relevance in the market (Vorhies et al., 2011), and the returns from managing a longer-term brand strategy are far higher than the associated costs to achieve it (Shocker and Weitz, 1998). International trade remains one of the most significant drivers of economic growth (WTO, 2018), so it is surprising to find there is a near void of academic research investigating international SBM; particularly, within a B2B setting. The realisation that effective branding strategies can assist B2B firms to grow or strengthen their position and profits within increasingly competitive 
markets (Wise and Zednickova, 2009; Worm and Srivastava, 2014) has led to a surge of systematic investment by suppliers into their brand related activities. Still, contemporary studies have revealed that managers are not clear about the mechanisms that links their B2B branding efforts to firm performance (Chang et al., 2018). We suggest that this lack of clarity is exacerbated by the contention that brand management theory and practices remain the most neglected and under-developed topic in branding (Merrilees et al., 2013) and least frequently studied area within the context of international marketing (Morgan et al., 2018). The increased scholarly interest in B2B branding has led to some significant recent empirical research endeavours examining various streams of B2B branding (e.g. Zablah, 2010; Worm and Srivastava, 2014; Coleman et al., 2015; Nguyen et al., 2018; Nyadzayo et al., 2018; Mohan et al., 2018); however, to our knowledge there has yet to be a study which addresses the effects of international SBM on export performance in the B2B context, hence a clear and important gap in the literature is evident. This study takes up the challenge set by Lilien (2016) and responds to recommendations for more B2B research to address the current gaps. Significantly, we bring together and advance B2B branding and international branding literature to provide an important contribution to knowledge by addressing the important role SBM has on fostering superior international firm performance. We also provide valuable practical managerial insights for executives involved in B2B international brand management. Through their examination into the history of branding Levy and Bastos (2012) assert that the ubiquity of the SBM concept is evident in the creation of thousands of brand manager jobs (Glassdoor.com, 2018), and most business schools now teach courses about brand management (Bastos and Levy, 2012). B2B branding research has traditionally been conducted from the buyers' perspective (e.g. Cretu and Brodie, 2007; Zablah et al., 2010); however, we have undertaken this study from the supplier standpoint. Another key element of originality within this study is the unit of analysis is at the firm level which is the most appropriate for examining B2B corporate brands (Mudambi, 2002). This differs from the growing tide of contemporary international marketing research which use the export venture as the primary unit of analysis (Chen et al., 2016). 


\section{Research Questions}

This study will address three main questions:

1) To what degree can a B2B exporter benefit from exploiting its international financial resources to attain enhanced international marketing capabilities?

2) What influence does exporters' international marketing capabilities have on international SBM practices in a B2B context?

3) To what extent do $\mathrm{B} 2 \mathrm{~B}$ exporters benefit from improved international firm performance through effective SBM practices?

The remainder of the manuscript is organised as follows. First we review the relevant literature, next we synthesise existing knowledge from the literature to produce an innovative conceptual framework along with specifying a basis for each construct used and hypothesis. Then, following the structure used by Ulaga and Eggert (2006) we first provide our qualitative study. Subsequently, we present our quantitative study where we describe our methodology and interpretation of findings relative to providing answers to the research questions. We conclude with a discussion of the results and consider potential implications for practitioners and suggestions for future studies.

\section{Review of Relevant Literature}

\section{Theoretical Background}

There is a broad consensus in the literature (c.f. Kaleka 2002; Zou et al., 2003; Morgan et al., 2004; Kaleka and Morgan, 2017) that resources and capabilities are fundamental drivers of competitive advantage and hence performance in overseas markets. This perspective has customarily been referred to as Resource Based Theory (RBT) (Barney et al., 2011; Kozlenkova et al., 2014) and the majority of international marketing studies investigating marketing capabilities have drawn from RBT (Morgan et al., 2018). In summary, RBT characterises a firm as a collection of heterogeneous physical, financial, human and organisational resources and capabilities (Barney and Hesterly 2012). This heterogeneity in a company's capabilities and how they are utilised to exploit available resources explains variations in firm performance (Makadok 2001; Barney and Hesterly 2012) with rare, valuable, 
inimitable and irreplaceable resources considered most beneficial (Wernerfelt, 1984; Barney, 1991). Superior performance relative to other firms in the same market is then possible through the acquisition and/or development of unique capabilities (Dhanaraj and Beamish 2003). Capabilities must be both hard to imitate and impossible to substitute, otherwise competitive advantage could be competed away over time (Barney, 1991).

An important perspective of RBT in the marketing literature is that it is grounded in market based resources and capabilities, such as branding, relationships and knowledge, which regularly differ from resource based studies in non-marketing contexts (Kozlenkova et al., 2014). This market-based resource perspective advocates that marketing research should increase focus on intangible, complementary resources and capabilities, whose effects on the firm's Sustained Competitive Advantage (SCA) and performance may be greater than the effects of tangible resources (Srivastava et al., 1998). This is supported by the fact that up to $70 \%$ of a firm's market value can be generated from its intangible resources and capabilities (Capraro and Srivastava 1997), such as branding related capabilities, which reiterates the importance of robust SBM. RBT provides a useful perspective for understanding how branding activities can create value leading to competitive advantage (Glynn and Woodside, 2009). Within the marketing strategy literature branding is the most studied market based resource using RBT (Kozlenkova et al., 2014). Within our study, we focus on the investigation of internal determinants of export performance, specifically focusing on international branding and therefore appropriately adopting a RBT approach.

\section{International SBM related Literature in the B2B Context}

In the era of globalisation whereby buyers have access to many more goods and services, branding is considered pivotal for successful internationalisation of emergent market firms (Erdogmus et al., 2010). The brand is a strategic reference point and can structure business development by providing alignment between the capabilities of a firm and the external environment (Wong and Merrilees, 2007). Continual changes and developments in the B2B 
market environment are eroding geographical barriers; therefore, it is now crucial for B2B firms to pursue international branding in their market offerings (Kotler and Pfoertsch, 2006).

A fundamental question within the marketing discipline is: what effect does a firm's marketing activities have on explaining performance outcomes? (Katsikeas et al., 2016). The importance of finding the answer is even more pertinent for exporters due to additional costs associated with conducting overseas trade. Exporting is the most common method for firms to enter international markets (Leonidou et al., 2002). Although domestic market branding literature has been rapidly developing over the past four decades, international branding literature has been surprisingly scant. For example, branding was not even mentioned as one of the article topics analysed by Nakata and Huang (2005) within their wide-ranging review of over 600 papers within the international marketing literature for the decade 1990-2000. A comprehensive meta-analysis of marketing strategy determinants of export performance did attempt to look at branding (Leonidou et al., 2002). However, the authors surmised that studies that had attempted to investigate branding (e.g. Kaynak and Kuan, 1993; Namiki, 1994) took a broad approach to branding without reference to a specific dimension; for example, branding capabilities or SBM which are investigated within this study. This lack of detailed analysis of branding within an international context creates an inherent problem when it comes to examining the association between branding and export performance since it is then difficult to identify which important aspects of branding, such as SBM skills, actually influence performance (Leonidou et al., (2002). However, there is increasing interest in how effective brand management can affect the performance outcomes of firms (Farris et al., 2010). According to Whitelock and Fastoso (2007. p266) “international branding is a field within international marketing concerned with the challenges that companies face when their brands cross national borders. These challenges relate to the essence of the brand in terms of brand name, brand visual (e.g. logo, colours) and sound elements (e.g. jingles, music), and brand personality". This suggests that the strategic management of international branding refers to the entire process of brand development and maintenance at an international level. Successful SBM requires corporate long-term involvement and a high level of resources and skills to become the referent brand (Kapferer, 2012). Within a domestic market setting, it has been 
found that a B2B brand management system (e.g. the CEO's interest in the brand, the power of the brand manager, employee training and education) is stronger for customer preference when compared with B2C brands (Lee et al., 2008). Some scholars regard brand management as a higher-level integrative marketing capability (e.g. Vorhies and Morgan, 2005; Morgan et al., 2009). Morgan et al., (2018) classify brand management capability as the least frequently studied type of international marketing capability. However, among discussions by the leading academics in the field of SBM it is not referred to as a capability (e.g. Rosenbaum-Elliott et al., 2011; Kapferer, 2012; Keller, 2013). For the purposes of this study, SBM will not be referred to as a capability; however, the reasoning for considering it as higher order capability is not refuted.

A further consideration surrounding B2B branding is the distinction between corporate or individual product branding and the approach B2B companies have towards the architecture of their branding strategy (Beverland et al., 2007; Keller, 2015). Unlike B2C companies, B2B suppliers are more likely to employ a 'branded house' strategy using a corporate umbrella brand for all of the products they offer (Keller 2015). This difference in the brand management approach is important for two reasons. First, corporate brands are held to be more important than product brands (Aspara and Tikanen, 2008) because of the profound effects that, for example, a brand failure may have on a large number of products the supplier may be offering to the market. Secondly, a large proportion of the extant literature in export performance pertaining to the management of the brand has been carried out at a venture-level using a single product or product line exported to a specific foreign market as the primary unit of analysis (Cavusgil and Zou, 1994; Morgan et al., 2004; Chen et al., 2016; Oliveira and Cadogan, 2018), implying a "house of brands" strategy which is incompatible with B2B brand strategy. As such, it is debatable whether this body of literature reliably reflects the unique challenges associated with the management of the B2B brands and the supplier's export performance. In addition, studies that measure export venture performance utilising export function instruments may lead to the suggestion of managerial implications which are invalid (Oliveira et al., 2012). Oliveira and Cadogan (2018) justify the need to revisit previous venture level studies and advocate the use of multi-level models if the export venture is going to be used to avoid a biased picture of 
export performance being formed. This again exposes a gap in the literature relating to international branding in a B2B context. Therefore, although research has looked at B2B branding, and this has become a growing area of research interest, the effect of B2B branding on export performance clearly lacks the empirical examination that sufficiently reflects the idiosyncratic nature of brand management in this specific context.

\section{Export Performance}

Previous studies focusing on branding, both within a domestic and international context, have generally focused on 'brand performance' instead of 'firm performance', though some studies have used measures of brand performance such as market share and profit (Ehrenberg et al., 2004; Coleman et al., 2015), that also can be found as measures of firm performance within the international marketing literature. Research into the measurement of brand performance is variable and inconsistent - it has been measured in many different ways and from numerous different viewpoints (Wong and Merrilees, 2007). Chabowski et al., (2013) reinforce this view and their bibliometric analysis of global branding literature concluded brand performance has taken a wide range of formats. Therefore, a key feature of this research is to investigate the direct influence of effective international SBM on firm performance in a B2B context. It is important to decide early on the sort of international performance that research is interested in examining (Cadogan, 2012). We take the position that performance is multidimensional (Katsikeas et al., 2000; Hultman et al., 2011) and therefore the potential influence of SBM on export performance should be explored both in terms of financial and market performance.

Export Financial Performance: Strong brands have become a vital part of the asset value of a firm (Madden et al., 2006). Before 1980 when firms were acquired or merged, the price paid relative to the firm's earnings as a ratio was normally in the region of around eight to one; however, after 1980, multiples of twenty to one became accepted as standard (Aaker, 1991). This can be attributed to an increasing realisation that strong brands are important to a firm's long term financial success and brands have progressively become viewed as one of a firm's most important assets (e.g. Fischer and Himme, 2017; Guitart et al., 2018). 
Export Market Performance: Strong brands with a positive brand equity will have a loyal core of repeat customers and subsequently retain a high market share and sustain future earnings (Torres et al., 2012; Nguyen et al., 2018). Having high brand loyalty means firms can usually charge comparatively higher prices and maintain higher margins than international competitors (Rosenbaum-Elliott et al., 2011). Therefore, even in situations whereby firms are not experiencing current high levels of financial success 'the brand is a potential source of future profits' (Kapferer, 2012). For example, this could translate into increased sales to existing customers as they perceive the risk of larger orders reduces due to brand strength or the fact that a strong brand can act as a deterrent to new potential competitors from entering the market (Himme and Fischer, 2014). Glynn (2012) called directly for the contribution of B2B brands on market performance to be explicitly examined.

\section{Conceptual Framework}

Our conceptual framework (Figure 1) comprises of four sets of factors: International financial resources, International marketing capabilities, International SBM and Export firm performance. International financial resources can be exploited to achieve improved marketing capabilities. The level of financial resources a firm possesses is a defining factor for a firm's ability to utilise it's capabilities (Josephson et al, 2016). Exporters' international financial resources relate to their ability to access cash and capital (Gomez-Mejia, 1988). It has been established in previous RBT studies that international financial resources are vital for B2B exporters seeking to compete in export markets (Kaleka, 2002; Spyropoulou et al., 2010). International marketing capabilities are central constructs in RBT, either fostering or diminishing SBM (Kozlenkova et al., 2014). According to Morgan and Slotegraaf (2012.p90) marketing capabilities are defined as "the processes by which organisations define, develop and deliver value to their customers by combining, transforming and deploying their resources in ways that meet market needs". Based on this definition the specific international marketing capabilities investigated in this study are, firstly, marketing information capabilities which refers to the processes firms employ to learn about their markets and use market knowledge 
(Vorhies and Morgan 2005). Secondly, international branding capabilities refers to a firm's ability to utilise available resources to present and communicate a simple brand meaning, use branding as an operational tool, treat their brand(s) as an asset and ensure staff understand and support their brand(s) meaning and values (Merrilees et al., 2011). International branding capabilities provide a promise of quality, simplifying choice, reducing risk and engendering trust for their overseas customers (Keller and Lehmann, 2006). Lastly, international marketing planning capabilities reflect a firm's ability to create and decide upon the optimal international strategy among alternative courses of appropriate marketing and branding actions (e.g. Slotegraaf and Dickson, 2004).

Capabilities are a key factor within studies of international business; however, management factors are also recognised as being critical to business success (Chen et al., 2016). Brand management draws from a combination of various marketing capabilities (Morgan, 2012). It is notable that RBT was initially developed in the strategic management discipline (Barney and Clark, 2007; Kozlenkova et al., 2014). Therefore, our innovative conceptual framework includes the inter-relationship between international marketing capabilities and international SBM. International SBM, which refers to the systems and processes used to cultivate, sustain and leverage brand assets internationally (Morgan, 2012), can both promote or deter international firm performance. It is central to RBT that the potential return of a firm's strategies is dependent on their resources and capabilities (Barney, 2014), thereby supporting the notion that the ways in which B2B firms' strategically manage their brands in overseas markets is reliant on the attributes of their antecedent resources and capabilities. Export firm performance can be determined using both financial and market measures. Commonly accepted measures of export financial performance include export profitability, return on investment (ROI), export margins and reaching export financial goals (Morgan et al., 2012). Widely accepted measures of export market performance include market share growth, growth in sales revenue, the ability to acquire new customers and increasing sales to existing customers (Vorhies et al., 2005; Morgan et al., 2009). B2B firms' which engage in SBM can expect performance benefits, including a boost to their earnings and the ability to command a premium stock price among investors. 


\section{("Insert Figure 1 about here")}

\section{Hypotheses}

\section{International Financial Resources and International Marketing Capabilities}

The strategic process of internationalisation requires access to considerable financial resources which explain the capital available for a firm to develop export markets (Freeman et al., 2012). Good international B2B brands need to be created and their formation is a complex practice involving a wide range of activities on behalf of the brand. For example, market research, planning, positioning and effective management that are predicted to lead to positive attitudes and perceptions towards the functional attributes of the brand (c.f. Aaker, 2004; Wong and Merrilees, 2007, Kuhn et al., 2008). Owing to the substantial working capital and financial requirements of these activities, the establishment and subsequent management of a solid international brand in any context is an expensive process (c.f. Boulding et al., 1994; Spyropoulou et al., 2011; Keller, 2013). For example, from a margin growth perspective, constructing and utilising the capabilities necessary to create, manage and leverage high levels of brand awareness and, positive, strong and unique brand associations in the minds of target buyers is expensive (Keller, 2003; Morgan et al., 2009). The availability of sufficient financial resources stimulates the deployment of vital marketing capabilities in export markets (Spyropoulou et al., 2011), hence we hypothesise:

H1 (a). A firm's International Financial Resources are a positive determinant associated with the development of its International Market Information Capabilities.

H1 (b). A firm's International Financial Resources are a positive determinant associated with the development of its International Branding Capabilities.

H1 (c). A firm's International Financial Resources are a positive determinant associated with the development of its International Marketing Planning Capabilities.

\section{International Marketing Capabilities and International SBM}

The possession of capabilities which relate to the acquisition of market information is expected to influence strategic branding considerations. This is regardless of whether firms wish to 
emphasise branding activities that accentuate differentiation of their products and services, or cost efficiencies which their brand can provide through the quality of their offering (Reimann et al., 2010; Vorhies and Morgan 2005). Morgan et al., (2009) surmise that greater access to market information allows a firm to identify underserved segments of the international marketplace and those markets whereby competitor's offerings may not be fulfilling customer requirements. For example, if quality is an issue in a given market then a B2B brand which embodies quality could use this market information to contend for a stronger position or initiate orders if it was a new market. "A strategic approach to branding is important to ensure that brands leverage the most recent and relevant market information into creating more powerful brands, ones that have strong market positions" (Merrilees et al., 2013. p146). Vorhies and Morgan (2005) interpret market information capabilities as a mid-level marketing capability, and brand management as a higher-level capability. They found market information capabilities have a significant positive effect on firm performance. However, they recommended further research should assess brand management. Based on these discussions, we posit the following hypothesis:

H2. The development of International Market Information Capabilities are a positive determinant in relation to the achievement of improved International Strategic Brand Management.

Branding can be interpreted as a higher-level marketing capability (Merrilees et al., 2011) that is posited as an antecedent to effective SBM. The effect of brand capability development on brand performance has been considered by various scholars (e.g. Morgan et al., 2009; Merrilees et al., 2011). Morgan et al., (2009) investigated brand management capabilities alongside other capabilities in terms of potential links to a firm's profit growth. Other studies have looked at brand capabilities separately to the way that those capabilities are then managed (Merrilees et al., 2011; Santos Vijande et al., 2013). Yet, an all-encompassing evaluation of the relationships between key marketing and brand capability development and SBM leading to enhanced firm performance has yet to be conducted. Further, not all studies have been specifically within a B2B domain and this presents the possibility that previous studies have utilised variables for measuring branding capabilities which are not specific to B2B markets. A thorough review of 
the literature has found that an overlooked essential element within previous measures of B2B branding capabilities is the ability for B2B brands to reduce uncertainty associated with the purchase making decision (Leek and Christodoulides, 2011; Lilien and Grewal, 2012, Mohan et al., 2018). We therefore can predict:

H3. The development of International Branding Capabilities are a positive determinant in relation to the achievement of improved International Strategic Brand Management.

Morgan and Slotegraaf (2012) interpret market planning capabilities as a mid-level marketing capability. Planning is recognised to be an effective tool in dealing with the uncertainty created by frequent and quick changes in the environment (Gray and Mabey, 2005) which can be prevalent within the field of international marketing. Marketing planning capabilities also include the capacity to segment markets (e.g. Vorhies and Morgan, 2003), the identification of attractive markets to target and appealing value propositions that will enable the firm to achieve its strategic objectives (e.g. Narver and Slater, 1990). Marketing planning capabilities encompass the firm's ability to envisage marketing strategies that elevate the linkage between a firm's resources and its marketplace (Morgan et al., 2003). Importantly, the link between marketing planning and SBM in any domain has been an overlooked issue. SBM is a form of competitive strategy; competitive strategies are planned patterns of capability deployments that support options about how the international firm will compete for its target buyers and achieve its desired goals (Murray et al., 2011). Exporters which can demonstrate greater planning will have a better understanding of the investment and financial resources required to develop and manage their distinctive brand offering abroad; therefore, enabling them to outperform international competitors by serving overseas markets more effectively (Weerawardena and O’Cass, 2004; O'Cass and Ngo, 2012). As such, we contend that robust marketing planning capabilities will deliver firms a prerequisite co-aligned capability which can influence their SBM in foreign markets, thus we hypothesise:

H4. The development of International Planning Capabilities are a positive determinant in relation to the achievement of improved International Strategic Brand Management. 


\section{International SBM and Export Performance}

Clearly there are benefits to having a strong B2B brand (e.g. Homburg et al., 2010; Glynn, 2012; Leek and Christodoulides, 2012); however, the creation of a brand is not an end in itself, it needs to be strategically managed as a business tool - an instrument for company growth and profitability (Kapferer, 2012). Even strong brands fail without proper management (Golder, 2000). Since a brand is reflected in everything that a company does, a complete branding approach requires a strategic perspective (Kotler and Pfoertsch, 2007), potentially explaining why in recent years B2B marketing is becoming distinctly more strategic (Wiersema, 2013). SBM encompasses the design and implementation of marketing programs and activities to build, measure and manage brand equity (Keller, 2013). Managers need to expertly utilise their SBM and actively develop these skills in order to advance unique methods of conveying superior value to customers therefore realising a favourable export branding position (Keller and Lehmann, 2006; O'Cass and Ngo, 2007), which in turn will lead to increased export performance (Spyropoulou et al., 2011). Thus we hypothesise:

H5 (a). Superiority in International Strategic Brand Management is a positive determinant associated with a firm's Financial Performance in overseas markets. H5 (b). Superiority in International Strategic Brand Management is a positive determinant associated with a firm's Market Performance in overseas markets

\section{Research Design}

The pragmatic, mixed methods approach to conducting research has a wide practical appeal and is suitable for this study to answer the research questions. Therefore, we chose to use a mixed methods approach which can generate outcomes that are more convincing and provide a better understanding of research problems than results from single methods alone (Stewart, 2009; Creswell and Plano Clark 2017) since single method studies can restrict the scope of research and contain certain inherent biases (Deshpande, 1983). Benefits of our mixed methods approach include data triangulation, the notion of completeness, the concept of instrument development, the notion of confirm and discover and 'utility' or improving the usefulness of findings (Bryman, 2006). Although there have been around forty mixed methods 
designs reported in the literature (Tashakkori and Teddlie, 2003), Creswell (2009) identifies the six most used forms of mixed methods research designs categorised under the two principle headings of sequential or concurrent designs. For this study we adopted a suitable sequential exploratory design (SED) which is characterised by an initial stage of qualitative data collection and analysis followed by a second stage of quantitative data collection and analysis. This was an appropriate design for our study given the absence of any previous research looking at the antecedents and effects of International SBM on export performance in a B2B context. The concept of International SBM within any context is underdeveloped but within a B2B setting it is particularly immature due to a lack of theory and previous research. This characterised the need for an initial qualitative piece of research to advance our understanding of the relevant measures and interrelationships (Morse 2016). Using a SED enabled the validation of themes we explored within the qualitative stage to occur within the quantitative stage (Teddlie \& Tashakkori, 2009) and the development of the quantitative stage to be reinforced and advanced by the qualitative findings. Since a strong focus of our study is to test the relationships within our conceptual framework, we have therefore placed greater emphasis in this paper on reporting our quantitative study over our preliminary qualitative field study findings, notated as qual $\rightarrow$ QUAN (Creswell and Plano Clark, 2017). The presentation of the research design findings follows that of Ulaga and Eggert (2006).

\section{Qualitative Study}

\section{Research Rationale}

In the first phase of the research we employed a qualitative approach which has the ability to represent the wider picture of the research problem and this perspective ensures consideration of all relevant concepts in the research design (Glynn and Woodside, 2009). The method of indepth interviewing was used. Specifically, qualitative, “open-ended," semi-structured interviews with "key informants" (i.e. personnel with senior positions) in the participating companies, since typically senior people drive corporate brands (Aaker and Joachimsthaler, 2000). This method is not capable of producing results which can be generalisable to reflect 
the population; however, it is an excellent way to gain an initial understanding that can be developed upon (Malhotra, 2010) by providing a primary evaluation of the relevant variables identified within the literature. Further, through in-depth interviews, it is possible to produce a preliminary picture of the structure and strength of the inter-relationships between variables presented within the conceptual framework.

\section{Interview Sample}

The field research consisted of in-depth interviews with 34 senior managers and directors of eligible B2B firms based in the UK that export overseas. The sample of participant firms and individuals were identified through a number of means: (1) Recent B2B nominees or winners of the Business Quarterly Magazine (BQ) export awards; (2) B2B Members of the Borders export association (3) The FAME database. Prospective informants were initially approached by a postal invitation and pre-screened with questions about their firm and whether they would be willing to participate in an interview. Eligibility questions were asked to all participants to confirm they met every part of the eligibility criteria: 1) they are a UK based company; 2) currently exporting goods/services to companies overseas in a B2B capacity; 3) they have not taken any breaks from exporting. This ensured information collected was from a representative group of businesses. The roles of the key informants included Chief Executive Officer (CEO), Chief Operating Officer (COO), Managing Director (MD), Export Manager (EM), Sales/Marketing Director (SMD), Business Development Officer (BDO) and Communications Director (CD). This is displayed in Table 1. with other pertinent information about the qualitative study key informants and their firms. On average, the interviews lasted 79 minutes and the participating firms worked within a multitude of different industry sectors.

\section{("Insert Table 1 about here")}

\section{Interview Protocol}

To ensure there was consistency within each interview in terms of structure and topic area prompts and terminology, an interview guide (protocol) was developed (Creswell, 2009). 
General topic areas and leading questions were generated around particular dimensions of RBT, brand management and export performance. Measures used in prior studies concerning each dimension were used as a basis to formulate questions for the protocol. By using a narrative approach we were able to organise findings to create a coherent story to not only describe themes but also how those themes fit together (Spradley, 1979; Pratt, 2009). Similar to the methodology used by Kohli and Jaworski (1990) and Mudambi (2002), we were careful about the use of the word 'branding' in the interviews when discussing the variables that comprise international branding capabilities or international SBM. Therefore, attempting to avoid potential misinterpretations that branding can often be confused as being a reductive concept involving mainly attributes such as logo and colour (Inskip, 2004); branding is much more than just a logo (Kotler and Pfoertsch, 2007). Hence, follow up questions with regards to specific international capabilities and SBM skills the company possess allowed for the examination of international branding antecedents and effects without relying on differing perceptions from key informants on what constitutes a brand.

\section{Data Analysis}

All interviews were audio recorded and transcribed verbatim. The transcripts became the foundation from which the analysis was conducted. In many cases, there were additional notes taken in a logbook, these were also written up following each interview. We first used a form of holistic coding to capture the essence of extracts and set a preliminary foundation due to the large amount of data (Saldana, 2013). The next step was to move onto a selective coding process by undertaking pattern coding (Miles and Huberman, 1994) to identify the key variables and inter-relationships mentioned in the verbatim transcripts. Overall, the formal coding process from the transcribed results captured the key variables related to the central constructs and the related inter relationships with regards to UK firms exporting in a B2B context. Themes were then examined and relevant quotes extracted in preparation for the write up. 


\section{Field Study Findings}

Through our in-depth interviews several relevant important resources and capabilities were found to be important to developing B2B firms' international SBM leading to improved export performance. There was agreement by participant companies that financial resources are a central tenet for their exporting activities and vital for improving their capabilities. For example, within discussions on this topic one Managing Director stated "the internal resource is money really" (R4), while a Marketing and Communications Director made the point "We have access to capital so, if, I guess like everything else, we have to present the case to be able to get that funding ...... things like investing in brand training for all of our 50 sales people around the world over a couple of years, that costs a lot of money so there's an investment in that" (R24).

The role of international marketing and branding capabilities were found to be important influences on developing effective SBM in foreign markets. Key respondents from across different industries emphasised the contribution of international marketing planning and market information capabilities along with branding capabilities to the management of their brands. For example, one export manager supported the importance of international market information capabilities to mitigate risk for their brands in foreign markets "it's all done based on an awful lot of research and we don't do things on a whim so we are not up for risk that could have a negative impact on our brand" (R26). However, there were also examples of B2B exporters which did not put the same emphasis on the potential benefits of international market information to their SBM. The following statement is from the CEO of a market leading highly innovative technology firm "Part of our brand philosophy is to run faster than everyone else so they worry about us more than we worry about them" (R14).

The vast majority of respondents were in agreement that international branding capabilities are essential to their exporting activities and that the development of these capabilities is consequently critical to the strategic management of their brands overseas. One COO explained "All the staff understand our brand, they know how and why we work" (R29) which supports the assertion that branding capabilities play a prominent role when there is an integrated effort from all areas of the firm (Wong and Merrilees, 2007). One export manager 
noted "They \{buyers\} have to be certain you can deliver on your brand's promises" (R2), a sentiment which other respondents agreed; for example, the Managing Director from a leading medical device firm explained "The trust with our brand and our people and our products is an incredibly powerful thing, that really is the crux of our business" (R32). This has strong resonance with work by Leek and Christodoulides (2011) and Lilien and Grewal (2012) which has identified the importance of reducing risk and the uncertainty associated with the purchase making decision for B2B buyers.

The qualitative interviews revealed that the vast majority of firms create and follow international marketing plans. One Marketing Director commented "Our international marketing plan goes hand in hand with our business plan, we have a strategy and that strategy obviously includes how we can grow the company; growing the company is based on: where can we find new overseas markets and implement our plan" (R33). Consequently, the appropriate deployment of international planning capabilities affects exporters' ability to achieve strategic objectives with regards to the management of their brand as communicated by a Managing Director "Our true goals now are to get the American market sorted: establishing our brand in America is our goal for the rest of this year, just to get that sorted before we even look at $\mathrm{Oz}$, Canada..." (R11).

Finally, we found ample evidence to support the notion that international SBM is playing a central role within B2B exporters' activities; for example, one of the Marketing Directors we spoke to explained "It's a long-term approach we take to managing our brand" (R19). Another Managing Director stated "It is very strategic the way we manage our brand" (R6), and, a Business Development Manager stressed "You have to ensure that you're building and managing your brand image in foreign markets" (R22).

Based on our findings from the qualitative study we were able to gain a more comprehensive understanding of both the constructs and the potential inter-relationships specified within our conceptual model. We followed the strategy suggested by Creswell and Plano Clark (2017) to examine if our quantitative research questions or hypotheses were in need of refinement following the qualitative stage. We found a high degree of support for our RBT theory 
predictions and therefore we could see no reason to refine our initial research questions and hypotheses. The qualitative field study findings indicated that an additional item concerning the importance of using branding to reduce uncertainty for buyers within the transaction process should be added to the international branding capabilities construct specifically for international branding studies in a B2B context. Another pertinent finding to emerge was the suggestion that certain firms did not place the same emphasis on market information capabilities impacting their SBM in overseas markets.

\section{Quantitative Study}

\section{Sample and Research Context}

The sample frame for the second study comprised of the winners of the UK Queen's Award (QA) for International Trade over a five-year period, from the year 2012 to 2016. The QA is the UK's longest running award in recognition of international trade. To be considered for a QA for International trade prospective UK based applicants must first show they meet a strict set of eligibility criteria, including, demonstrating exceptional and consistent recent year-onyear growth and sales in export markets. (c.f. Gov.UK, 2019). The development of an appropriate sampling frame can be challenging in many countries, in particular, developing countries where secondary sources may not be able to provide reliable information about the target population (Malhotra, 2010). Given that this study was conducted in the UK, which is governed by stricter laws in terms of the recording and access to company data, some of the reliability concerns are eased. All participating firms had been exporting for at least five years and had the experience required to answer the questionnaire (e.g. Morgan et al., 2012). The majority of QA winners are SMEs; however, there are also large organisations with thousands of employees. It was established by Chen et al., (2016) within their comprehensive review of determinants of export performance literature, that a high number of studies (42) included small, medium and large sized firms. Therefore, this study conforms to previous studies' guidelines. We adopted a multi-industry research design including firms exporting both goods and services. The adoption of a multi-industry design allows for a wider variability in 
international SBM practices and reduces the likelihood of sampling bias, therefore providing greater generalisability (Bello and Gilliland, 1997). There is a higher risk of drawing invalid conclusions when scholars incorrectly match up levels of theory and measurement (Sousa et al., 2008), so it is vital that measurement equates to the level at which the theory has been developed (Cadogan et al., 2009). According to Chen et al., (2016) the decision upon which unit of analysis to use should be dependent on the research objectives, and venture level analysis does not work for all. Given that for this study of international B2B branding the theory is developed at the level of the firm using a branded house approach, it is therefore appropriate that the corporate firm will be used as the unit of analysis.

Table 2 provides characteristics from the quantitative study sample, $49 \%$ provide goods, $21 \%$ services and $30 \%$ provide both goods and services. Regarding the size of the firm, two measures are commonly used: 1) number of employees and 2) turnover. The highest number of firms had between 11-50 employees (41\%) between 51-250 (35\%), between 1-10 employees (10\%), more than $500(8 \%)$ and between 251-500 employees (6\%). Firms reported a wide range of turnovers, the highest was $33 \%$ within the $£ 1$ million to $£ 5$ million bracket, followed by $22 \%$ within the $£ 5$ million to $£ 10$ million bracket then $19 \%$ within the $£ 10$ million to $£ 25$ million bracket. Therefore, the sample reflected firms of various sizes from small, medium and large organisations. $70 \%$ of firms reported they attain between $50-100 \%$ of their overall turnover from exporting. The majority of firms (69\%) had more than ten years exporting experience. Participant firms were generally exporting to a high number of overseas markets. Only $21 \%$ of firms exported to under 11 markets, over $50 \%$ of firms were exporting to at least 26 markets and $28 \%$ of firms were exporting to at least 51 markets.

\section{("Insert Table 2 about here")}

\section{Data Collection}

For our study, the sample we used consisted of a database of QA winners which represent a group of high performance heterogeneous multi industry UK exporters of different sizes who have met defined performance and experience criteria and are located throughout every single 
region of the UK. The total number of firms within the QA database compiled from 2012-2016 consisted of 632 firms. In order to contact each firm, key respondents were identified through the QA press book and/or by calling the firm to briefly explain the research being conducted, provide notification of the forthcoming survey and identify the most appropriate key informant for the study by name and contact details. A postal pre-notification was also sent to each key informant with the request to add the domain name of the survey software provider (Qualtrics) to their safe senders list thereby reducing the likelihood of the survey dropping into their junk mail folder. A suitable survey protocol was followed and following the first wave, two reminder waves of the online survey were sent over a six week period. A total of 208 firms fully completed the questionnaire from the 632 firms contacted which represented a response rate of $33 \%$ and a sufficient sample size for conducting structural equation modeling (Hair et al., 2017). A further 79 questionnaires were incomplete and therefore, were not included within the analysis. A superset problem occurs when the sampling frame is in some way larger than the population but contains all the elements of the population (Aaker et al., 2011). In this study, the QA database compiled consisted of all UK firms exporting but does not differentiate for those mainly conducting B2C. The majority of firms conducting exporting activities are B2B (FSB, 2016); however, to reduce the likelihood of B2C firms being included within the sample, each firm in the QA database was first given an initial cursory review and any firms mainly operating in a B2C capacity were excluded. It was also necessary to include a filter question within the survey to establish those firms conducting B2C business which had not been identified within the initial review. This meant these firms could be omitted from this study.

\section{Questionnaire and Measures}

We used existing measures of the constructs needed to test our hypotheses. Specifically, we used the financial resources measures developed by Spyropoulou et al., (2011). Five items were scored using the same 7-point Likert scale running from 1 (Much Worse Than Competitors) to

7 (Much Better Than Competitors). Our International Market Information Management 
Capabilities was reflected by five items adopted from Vorhies and Morgan (2005). Participants were asked to rate their capabilities relative to their major competitors (in the most important export markets), scored using a 7-point Likert scale running from 1 (Much worse than competitors) to 7 (Much better than competitors). Our International Branding Capabilities scale was developed based on five items from the scale suggested by Merrilees et al., (2011) in their B2B specific study. An additional item was provided which was derived from the literature and the qualitative stage of the research, this was in relation to using branding to reduce uncertainty for buyers within the transaction process. Participants were asked to rate their level of agreement with statements scored using a 7-point Likert scale running from 1 (Strongly disagree) to 7 (Strongly agree). International Marketing Planning Capabilities was captured using the four item scale suggested by Morgan et al., (2012) which they developed by adapting the original scale used by Piercy and Morgan (1994). The four items were scored using the same 7-point Likert scale running from 1 (Much Worse Than Competitors) to 7 (Much Better Than Competitors). Strategic Brand Management was measured using the five item scale developed in a B2B context by Santos-Vijande et al., (2013). Participants were asked to rate their level of agreement with statements, scored using a 7 point Likert scale running from 1 (Strongly disagree) to 7 (Strongly agree). Finally, export performance constructs, consisting of both financial performance (four item) and market performance (four item), were captured using the two constructs and scales from Morgan et al., (2012). Each performance construct assessed the performance of the participant firms evaluated in terms of the performance of exporting activities relative to major competitors (within the firms most important export markets). The four item constructs were scored using a 7-point Likert scale running from 1 (Much Worse Than Competitors) to 7 (Much Better Than Competitors).

We include a number of controls in our hypothesis testing models. These included Exporter firm size, measured as both the number of employees and as the annual turnover; Firm experience, both as the number of years' trading and the number of years' exporting; Firms providing goods or services, the percentage of turnover attained through exporting and 
the number of export markets which they currently serve. For the purpose of parsimony, we opted to not include these additional estimates with the findings reported.

\section{Analysis and Results}

\section{Validation of Measures}

The constructs used within this study had been previously validated in earlier research projects. Although the construct 'International Branding Capabilities' had been previously validated and used in a B2B study by Merrilees et al., (2011), it originated from another study by Wong and Merrilees (2008) which was not specifically within the B2B domain. Given the inherent differences identified in $\mathrm{B} 2 \mathrm{~B}$ branding, a scale development process was conducted to determine if any further items should be incorporated. This responds to Leonidou et al.'s, (2010) appeal for more rigorous construct development and where necessary the adjustment of measurement scales. First, the conceptual domain of the construct was defined to identify what the construct is intended to conceptually represent and reasoning for how it differs from other related constructs (Spector, 1992). A review of relevant literature was the initial stage in developing the construct (Gerbing and Anderson, 1988). This review identified an additional item in relation to the fact that $\mathrm{B} 2 \mathrm{~B}$ firms differ in the regard that they are likely to use branding's functional attributes to reduce the uncertainty for buyers within the purchase making process (Mudambi et al., 2002; Lilien and Grewal, 2012). The views of experts in the field was then sought along with the target population through the qualitative stage of the study. Broad support was found for the additional item to be added within B2B branding capabilities. The initial 7-point attitudinal Likert scale was considered suitable and therefore, it was a less complex process to add the extra item within the existing measurement model to ensure all parameters of the model had been identified (Gerbing and Anderson, 1988). A pilot study did not raise any concerns about the validity of the additional item within the construct or the manner in which the new item was written (Podsakoff et al., 2003). Next, we examined the psychometric properties of the new scale using Exploratory Factor Analysis (EFA), the Goodness of Fit of the measurement model was assessed using Confirmatory Factor Analysis 
(CFA) and the validity and reliability of the measure with the new item was evaluated. The correlations matrix produced through EFA showed that all items correlate above 0.4; therefore, well above the required 0.3 required to indicate an EFA can be conducted (Pallant, 2013). The Kaiser-Meyer-Olkin measure of sampling adequacy (KMO) was 0.876 , well above the critical value of 0.6 and the Bartlett's test of Sphericity was significant with a P value of 0.000 . In order to maximize variance, principal components factor analysis with varimax rotation method was conducted. The result of the analysis was a single factor comprising of the six items explaining $64.139 \%$ of the total variance in the international branding capabilities construct; therefore, above the recommended $60 \%$. Table 3 displays the results of the component matrix as part of the EFA, showing each item within the factor, including the new additional item in bold, loads highly above the recommend value of 0.5 (Hair et al., 2014).

\section{("Insert Table 3 about here")}

Following the EFA, a CFA was conducted for the construct International B2B branding capabilities (the new international branding capabilities scale with the added item) as suggested by Gerbing and Anderson (1988) and DeVellis (2003) who advocate the combined use of EFA and CFA. The results from the CFA also indicate an acceptable model fit for the developed construct with the additional item, $(\mathrm{p}<0.001)$ with 9 degrees of freedom and $\chi^{2}=33.802 \mathrm{CFI}=$ 0.990, $\mathrm{TLI}=0.978, \mathrm{GFI}=0.979, \mathrm{NFI}=0.979, \mathrm{RMSEA}=0.067)$. Each of the factor loadings was statistically significant. Composite reliability is above the 0.70 suggested $(0.892)$ and the Average Variance Extracted (0.58) is above the recommended lower level of 0.50 recommended (Fornell and Larcker, 1981). The developed construct reliability was also evaluated using Cronbach's alpha, the internal reliability estimates for International B2B branding capabilities (0.887) is well within the recommended level of 0.7 (Nunnally, 1978). Based on these results the construct developed with a further new scale item was acceptable.

We also performed a CFA to assess the validity and reliability of our entire measurement model for the items representing the seven constructs of export financial resources, marketing 
information capabilities, international branding capabilities, international marketing planning capabilities, international strategic brand management, export financial performance and export market performance. For the CFA, each item was restricted only to load on its related specified factor and were permitted to correlate with one and another. To further refine the measurement model, we removed items with low factor loadings (-) and then re-ran the CFA (see table 4).

\section{("Insert Table 4 about here")}

Table 5 presents a summary of the results of the final measurement model; including, the average variance extracted (AVE) and composite reliability (CR). The chi square $\left(\chi^{2} 464.845\right)$ of the model is statistically significant $(\mathrm{p}<0.000)$ with 338 degrees of freedom. The fit indices assessed all indicated a good fit between the data and the model, with CFI $=0.971$, NFI $=$ 0.903, $\mathrm{IFI}=0.972 \mathrm{TLI}=0.965$, and RMSEA $=0.043$. Each item then significantly loaded on the respective construct they were intended to represent (the average factor loading was 0.83 while the minimum $t$-value was 7.808) indicating convergent validity (Gerbing and Anderson, 1988). Estimating AVE and CR is important for fully assessing construct convergent and discriminant validity (Fornell and Larcker 1981). Convergent validity is accepted when AVE is greater than 0.5 and CR greater than 0.7 (Bagozzi and Yi, 1988; Hair et al., 2014; Malhotra et al., 2010). Providing confirmation of this, each construct had high composite reliability (ranging from 0.875 to 0.927 ); therefore, far in excess of the 0.7 level. The AVE of each construct far exceeded the established 0.5 benchmark (Hair et al., 2014). In terms of internal consistency, for each of the constructs the Cronbach $\alpha$ coefficients exceeded the 0.7 benchmark which is suggested as the lowest accepted bound of Cronbach alpha (Nunnally, 1978); therefore, confirming their reliability as satisfactory. Discriminant validity exists when AVE is larger than the squared correlation between pairs of the factors (Fornell and Larcker, 1981). From an initial evaluation of discriminant validity, there was an issue identified with regards to a lower square root of two constructs (international branding capabilities and international 
strategic brand management) than the correlation between them (Malhotra, 2010). Further exploratory factor analysis investigation uncovered some cross loading for 'item 5 ' of the construct international strategic brand management onto international branding capabilities, therefore this item was removed from the construct and when the analysis was again conducted the discriminant validity issue was resolved.

\section{("Insert Table 5 about here")}

\section{Non-Response Bias}

To assess the issue of non-response bias we used a wave analysis technique also referred to as the Linear Extrapolation Method (Armstrong and Overton 1977). The technique that best fits this research is extrapolation carried over successive waves of the questionnaire. We sent two follow up/reminder emails subsequent to the initial online survey; thereby, creating three waves. Comparisons were made between early and late respondents across the three waves with respect to various firm characteristics, including number of employees, number of years conducting international trade, goods or services and annual turnover. We compared early and late respondents using a commonly used parametric test (t-test) procedure. A number of t-tests were performed, which confirmed no differences exist at the established 0.05 level between early and late respondents.

\section{Common Method Bias}

Two approaches were taken to test for Common Method Bias (CMB). First, we followed the procedures recommended for 'Harman's single factor test'. The factor analysis comprising all variables was run in SPSS with no rotation, and extraction set to one. The results showed the single factor extracted accounted for less than $25 \%$ of the variance which is well under the $50 \%$ threshold (Podsakoff, 2003); therefore, the test found no bias. However, arguably the single factor test can be conservative in detecting biases (Malhotra et al., 2010); therefore, further tests were also conducted. According to Podsakoff, (2003), a good approach is controlling for the effects of an unmeasured latent methods factor, referred to as a Common Latent Factor 
(CLF). A benefit of this approach is it does not require the researcher to identify and measure the specific factor responsible for methods effects. Additionally, this approach models the effect of the method factor on the measures instead of the latent constructs they signify and does not need an equal effect on each measure by the method factor (Podsakoff, 2003). To conduct the test, we followed established procedures for creating and testing using a CLF in CFA using Podsakoff's (2003) method whereby items are allowed to load onto their constructs along with a CLF and the significance of the structural parameters are assessed with and without the inclusion of the CLF. There were no significant differences found between the standardised regression weights estimates with and without the CLF present and therefore, no need to include common method adjusted composites within the structural model.

\section{Hypothesis Testing}

We tested our hypothesised model using maximum likelihood estimation in a structural equation model facilitated through the software AMOS version 25. The goodness-of-fit indices for our hypothesised full structural model $\left(\chi^{2} 118.262\right.$, d.f $=49, \mathrm{p}<0.000 ; \mathrm{CFI}=0.954, \mathrm{NFI}=$ $0.931, \mathrm{IFI}=0.961 \mathrm{TLI}=0.914$, and RMSEA $=0.78)$ indicate a good overall fit. As a robustness check we also tested an alternative model adding direct paths between the three international marketing capabilities and the two export performance outcomes. Reassuringly, the nature of the results for the hypothesised relationships are unchanged between the two models. Although this alternative model provided some improved fit indices it also provided a non-significant chi-square result $\left(\chi^{2} 59.550\right.$, d.f $\left.=43, \mathrm{p}>0.05\right)$ so we did not adopt this model and instead continued with our initial default model as the focus for our paper. Displayed in Table 6 it can be seen that as hypothesised in $\mathrm{H} 1 \mathrm{a}, \mathrm{H} 1 \mathrm{~b}$ and $\mathrm{H} 1 \mathrm{c}$, financial resources was found to have a positive link with (H1a) international market information $(\beta=0.391, t=6.104, p<0.001),(H 1 b)$ international branding capabilities $(\beta=0.141, \mathrm{t}=2.169, \mathrm{p}<0.05)$ and $(\mathrm{H} 1 \mathrm{c})$ international marketing planning capabilities $(\beta=0.451, \mathrm{t}=7.273, \mathrm{p}<0.001)$. In terms of international marketing capability antecedents of SBM, our results did not support $\mathrm{H} 2$, and no significant link was found between international market information capabilities and SBM $(\beta=0.036, t=$ 
$0.618, \mathrm{p}>0.1)$. However, there was strong support for $\mathrm{H} 3$ and a very strong link was found between international branding capabilities and $\operatorname{SBM}(\beta=0.7, \mathrm{t}=17.67, \mathrm{p}<0.001)$. In line with this, $\mathrm{H} 4$ revealed a strong link between international planning capabilities and $\mathrm{SBM}(\beta=0.22$, $\mathrm{t}=3.819, \mathrm{p}<0.001)$. SBM was found to be positively related to both export market performance $(\beta=0.18, t=2.628, p<0.001)$ and export financial performance $(\beta=0.263, t=3.904, p<0.001)$, supporting $\mathrm{H} 5 \mathrm{a}$ and $\mathrm{H} 5 \mathrm{~b}$ respectively.

In addition, with regard to the role of control variables in the model, the results indicate a significant positive relationship between the percentage of turnover attained through exporting and both market performance $(\beta=0.232$, t-value $=3.326, \mathrm{p}<0.001)$ and financial performance $(\beta=0.176, \mathrm{t}$-value $=2.508, \mathrm{p}<0.001)$. There was also a significant link observed between the number of years exporting and market performance $(\beta=0.113$, $t$-value $=1.865$, $\mathrm{p}<0.001)$. All other direct effects of the export firms characteristics which were controlled for on the two performance dependant measures were found to be non-significant.

\section{("'Insert Table 6 about here")}

\section{Mediation Tests}

Our overall aim was to examine the effect of International SBM on export performance within the Business to Business (B2B) context. Consistent with RBT, our conceptual framework shows that international SBM has a direct influence on export performance and certain antecedent international marketing capabilities directly effect international SBM in a B2B context. Although our model does not warrant a direct link between international marketing capabilities and export performance we conducted a set of mediation tests to complement our analysis. We utilised the method of analysis and reporting results detailed in (Hayes, 2013) which involves the use of bootstrapping and confidence intervals. As such we conducted six additional analyses using bias-corrected bootstrap intervals for the indirect effect of each of the three international marketing capabilities on each of the two export performance constructs, based on 10,000 bootstrap samples. Consistent with the findings of our prior hypothesis $(\mathrm{H} 2)$, the results indicated that the mean indirect effect of the interaction between international 
market information capabilities on 1) export market performance and 2) export financial performance through international SBM is not significant. These results are 1) $a b=0.009$, $\mathrm{p}>0.05$ (-0.16 to 0.042$)$ and 2$) \mathrm{ab}=0.009, \mathrm{p}>0.05$ (-0.016 to 0.044$)$. The results indicated that the mean indirect effect of the interaction between international branding capabilities on 3) export market performance and 4) export financial performance through international SBM is positive and significant. These results are 3$) a b=0.171, p<0.05(0.092$ to 0.25$)$ and 4) $a b=0.181, p<0.005(0.098$ to 0.262$)$. Our last set of results indicated that the mean indirect effect of the interaction between international planning capabilities on 5) export market performance and 6) export financial performance through international SBM is positive and significant. These results are 5$) \mathrm{ab}=0.05, \mathrm{p}<0.005(0.018$ to 0.099$)$ and 6$) \mathrm{ab}=0.052, \mathrm{p}<0.05$ (0.019 to 0.104$)$.

\section{Discussion}

SBM is vital to firms performance outcomes (e.g. Rosenbaum-Elliott et al., 2011; Kapferer, 2012; Keller, 2013) yet there is a knowledge deficit when it comes to academic research investigating international SBM; particularly, within a B2B setting. This is a critical gap in the literature given the importance of B2B branding (Michaelidou et al., 2011) and the economic value of global B2B transactions (Lilien, 2016). However, the fact remains that a brand is not an end in itself, it still needs to be managed strategically for what it is - a business tool which acts as an instrument for firm growth, profitability and sustained long term performance (Kapferer, 2012). In their review of RBT literature Kozlenkova et al., (2014) suggested that the main purpose for which researchers in the field of marketing use RBT is to provide a theoretical framework that can explain how specific marketing related activities can lead to improved long term performance. Therefore it was appropriate that we used RBT to investigate the antecedents and performance outcomes of international SBM in a B2B context, and, our findings mainly indicated strong support for our RBT theory predictions.

Overall our results first indicate that the possession and deployment of international financial resources are vital to building the antecedent capabilities required for effective SBM in a B2B context. The resources were found to possess a significant influence over international 
marketing capabilities; namely: market information capabilities, branding capabilities and marketing planning capabilities. This could be attributed to the relatively high working capital and financial liquidity requirements of B2B export operations (Spyropoulou et al., 2010). These findings are in line with previous research by Spyropoulou et al., $(2010 ; 2011)$ looking at the effects of financial resources on relationship management capabilities, communications capabilities and branding advantage. However, this study extends knowledge by focusing solely on a B2B context and confirming the effects of international financial resources on a set of international capabilities (market information, branding and marketing planning) which have not previously been tested. The results from this study provide a contribution to the international marketing literature by providing empirical confirmation that possession of suitable financial resources is advantageous to the deployment of market information, marketing planning and branding capabilities in export markets. These key findings are linked to suggestions in the international marketing literature that developing; 1) strong long-term market information capabilities is an expensive process (Eriksson et al., 1997); 2) developing robust branding capabilities is a costly endeavour (Keller and Lehmann, 2006) and 3) a considerable investment is required to support a firm's intention to build and support substantial comprehensive marketing planning capabilities (Gilligan and Wilson, 2009).

Contrary to expectations B2B international market information capabilities were not found to exhibit a significant positive influence over international SBM practices. This is particularly surprising given that a continuous flow of valuable market information can act as an exploratory force motivating already differentiated firms to further refine their offerings unique features or devise novel ways of differentiation (Kaleka and Morgan, 2017), as would be found by the strategic way a firm manages its brand. One explanation for this non-significant path might be that the positive effects of the exporting firm's international market information capabilities on its SBM are offset by the negative effect of the complexities and costs involved in acquiring and thoroughly analysing the available information for a wide range of export markets. Montgomery et al., (2005) found accessibility issues concerning collecting information about competitive behaviour and associated issues with regard to conducting analysis, limits firms' ability to engage with strategic competitive reasoning. In this study, 
only $21 \%$ of firms exported to under eleven markets and over $50 \%$ of firms were exporting to at least twenty-six markets. Therefore, the difficulties associated with acquiring and analysing adequate market information from a high number of export markets could be limiting firms' ability to achieve significant benefits by strategically managing their brand through their market information capabilities. Previous studies in the marketing and product development literature suggest that in more centralised and formalised organisations knowledge transfers can be less efficient and effective (e.g. Jaworski and Kohli, 1993; Moenaert and Souder, 1990). Therefore, a further potential reason for this non-significant effect could also be explained by a lack of appropriate market information knowledge being efficiently transferred to brand management teams within some organisations. This was the first time this relationship had been studied in an international B2B context; therefore, further investigation into this could be a future research concern.

As predicted, our findings revealed that robust branding capabilities have a very significant influence on providing effective SBM. A thorough review of the literature exposed that a potentially overlooked essential item within B2B branding capabilities is the ability for B2B brands to reduce uncertainty associated with the purchase making decision (Leek and Christodoulides, 2011; Lilien and Grewal, 2012) which is an inherent characteristic of B2B markets (Mudambi et al., 2002). The need for this important additional measure within the construct, international B2B branding capabilities, was then supported by the qualitative stage of our research and we followed accepted procedures for developing and testing this new item within our survey. This was a key finding and serves to broaden and deepen academic understanding; the newly developed international B2B branding construct provides a valuable contribution for future research efforts examining international B2B branding. International B2B brands serve several valuable functions (e.g. reduce risk, signify quality, engender trust), cumulatively targeted towards providing a competitive advantage in export markets. The establishment of robust international branding capabilities underpins B2B exporters efforts to effectively manage their corporate brand which in turn leads to stronger enduring relationships with their buyers and increased export performance. The marketing literature suggests that marketing planning capabilities relate to the ability of firms to conceive strategies that suitably 
align available resources and capabilities with marketplace conditions in ways that facilitate the firm to achieve its strategic objectives (Day and Wensley, 1988). Our findings demonstrate that $\mathrm{B} 2 \mathrm{~B}$ exporters that have strong planning skills and thorough export planning processes are more likely to make suitable strategic decisions in relation to the management of their brand, which will in turn lead to increased export performance.

This study is the first to test the influence of international SBM practices on export performance outcomes in a $\mathrm{B} 2 \mathrm{~B}$ context. Historically, there has been a lack of empirical evidence to guide managers' strategic brand decisions (Hill et al., 2005). Given the importance of brands to strategic marketing theory explanations of a firm's performance and the significant resources that firms expend on brand building and brand management, this is an important gap in marketing knowledge (Morgan and Rego, 2009). Our study addresses this gap and contributes to the growing streams of literature within B2B branding and international branding, by showing that the creation of effective international SBM is confirmed to be positively associated with export performance in the B2B domain. Importantly, in contrast to findings presented within earlier studies within the international branding and B2B branding streams of literature, we justified the use of the firm as the unit of analysis instead of the export venture, and findings from this study are based on a multi-industry sample inclusive of both goods and services providers. The originality of this study is amplified by the fact we have taken the suppliers standpoint instead of conducting research from the buyers perspective which has been synonymous with prior B2B branding research (Zablah et al., 2010; Leek and Christodoulides 2012). Therefore, we believe this study is the first to allow for generalisable statements about international B2B branding, specifically B2B branding capabilities and SBM within export markets.

\section{Managerial Implications}

It is acknowledged that a B2B firm's brand is a potential source of future profits in foreign markets (Kapferer, 2012). Yet, many practitioners in B2B markets are still uncertain as to whether the high, and sometimes prohibitive, investments generally related with building and establishing robust branding capabilities and SBM in overseas markets really pay off; this study 
has addressed this issue. We find support for the assertion that in a B2B context international SBM can provide an opportunity for firms to strengthen and differentiate themselves and the products or services they supply, allowing them to build their brand equity and gain a competitive advantage in overseas markets. Therefore, this study provides a calibration of the performance benefits resultant from the effective execution of international brand management strategies that should encourage B2B exporters to pay more attention to brand management issues than is normally the case. The function and purpose of international branding is clearly summarised by one Managing Director who articulated "It is all about performance; we don't consider branding like the NIKE tick and stuff like that; our markets don't really require that kind of level of branding, our brand is based on high quality, performance and reliability". Therefore, performance is critical to the way a B2B exporters brand is strategically managed. This study highlights and considers a number of practical insights for B2B firms wishing to develop their exporting activities. Given that effective international SBM has been established as a determinant of improved export performance, a central tenet of any B2B firm's export strategy should be their effective SBM. This important finding provides an opportunity for B2B exporters to justify their direct long term international SBM investments. International financial resource constraints mean it is essential for B2B exporters' to be able to set priorities. Therefore, the identification of key international marketing and branding capabilities which can enable them to exploit their financial resources for optimal benefits is critical. With this in mind, practitioners are advised to prioritise the development of robust international branding and marketing planning capabilities. This will allow them to focus on the essence of their brand and communicate their brand image through the effective strategic management of their brand to business customers evoking positive brand associations, enhanced perceived brand value and increased export performance.

Financial accounting does not account for intangible assets (Madden et al., 2006) such as a B2B exporters' branding activities. However, to be included in important business decisions export marketing managers' must fully comprehend key activities such as international SBM and be able to show clear links to financial performance affecting shareholder value (Cortez and Johnston, 2017). Therefore, it is crucial that exporting 
practitioners have knowledge of the existence and strength of connections between international SBM and export performance in a B2B context which this study provides them with.

\section{Limitations and Directions for Further Research}

The study findings should be regarded in the context of certain limitations that need to be taken into consideration, some of which offer fruitful avenues for future research. First, this research was conducted specifically in the context of $\mathrm{B} 2 \mathrm{~B}$ exporting activities for firms based in the UK. Therefore, the findings are, strictly speaking, limited to the activities of UK exporters; for this reason, care should be taken when applying these to other empirical settings. We recommend that this study is replicated in an emerging market setting to allow for further insights and comparisons to be made in relation to SBM's importance in a different market environment. A further limitation of this study is that empirical data were collected only from experienced effective B2B exporters. Consequently, this does not account for non-exporters which plan to initiate exporting. Therefore, longitudinal studies including both current exporters and firms planning to initiate exporting activities in a B2B setting would permit investigation into: 1) the role of temporal effects on the associations of the constructs within the emerging framework and 2) measuring export performance for businesses initiating exporting with differing levels of international capabilities and SBM processes against other existing effective exporters.

This research has provided a comprehensive B2B supplier perspective to SBM; however, the branding literature suggests brand value is dyadic in nature and implies both the exporter and importer contribute to building firms' international brand equity. Consequently, brand value is not only determined by effective SBM by the B2B supplier, but also by business customers' perception of the brand in question. So, to fully investigate the impact of a firm's international branding efforts and to promote further development of the conceptual framework, a novel and original approach is suggested. It is recommended to broaden the scope 
of investigation to include the views of importers in assessing the attractiveness (competitiveness) of competing exporters brands for their business. Furthermore, incorporating buyers from different cultural backgrounds will allow for future research to assess how culture affects buyers' perception of UK B2B brands in terms of B2B branding dimensions such as quality, trust and reduction of uncertainty within their purchasing decision making processes. Differences between perceptions could then also be compared by including importers from both established mature markets like the USA and European countries; for instance, Italy and Germany against emerging markets such as India and China. This provides scope for an abundance of future research and the potential for sizeable future breakthroughs for the benefit of both academics and managers approaching SBM.

\section{Conclusions}

The significant role of branding for increasing a firm's performance is firmly established for B2C firms, albeit less so when considering branding within an international context. However, the differences between: 1) consumer markets and industrial markets and 2) B2C brand management compared with managing $\mathrm{B} 2 \mathrm{~B}$ brands in an international context, mean findings from B2C branding studies cannot be relied upon when applied to a B2B domain. Therefore, this study was interested in providing an investigation into the clear gap that exists when considering $\mathrm{B} 2 \mathrm{~B} \mathrm{SBM}$ and exporting performance. With this study we have moved the boundaries of knowledge forward in a number of ways. Based on a set of 34 interviews and a large scale survey, we used a RBT approach and found that certain internal factors influence whether a B2B exporter can achieve improved SBM within international markets. For the first time SBM has been demonstrated to be a key deterministic factor of B2B export performance. Within an increasingly globalised marketplace, B2B firms which focus on their international SBM can expect improved financial and market performance in overseas markets. 


\section{References}

Aaker, D.A. (1991). Managing Brand Equity: Capitalizing on the Value of a Brand Name, Free Press, New York, NY.

Aaker, D.A. (2004). Brand Portfolio Strategy: Creating Relevance, Differentiation, Energy, Leverage, and Clarity, Free Press, Glencoe, IL.

Aaker, D.A. and Joachimsthaler, E., (2000). Brand leadership: The next level of the brand revolution. Free Press, New York.

Aaker, D., Kumar, V., Day, D. and Leone, R. (2011). Marketing Research. International Student Version. 10th Edition. John Wiley \& Sons.

Armstrong, J.S. and Overton, T.S., (1977). Estimating nonresponse bias in mail surveys. Journal of Marketing Research, pp.396-402.

Aspara, J. and Tikkanen, H. (2008). Significance of corporate brand for business-to-business companies: The Marketing Review, Volume 8, Number 1, March 2008, pp.43-60(18)

Bagozzi, R.P. and Yi, Y. (1988). On the evaluation of structural equation models. Journal of the Academy of Marketing Science, 16(1), pp.74-94.

Barney J. (1991). Firm resources and sustained competitive advantage. Journal of Management 17(1): 99-120

Barney, J.B. (2014). How marketing scholars might help address issues in resource-based theory. Journal of the Academy of Marketing Science, 42(1), pp.24-26.

Barney, J. and Clark, D. (2007). Resource-based theory: Creating and sustaining competitive advantage. New York: Oxford University Press.

Barney, J., and Hesterly, W. (2012). Strategic management and competitive advantage: Concepts and cases (4th ed.). New Jersey: Pearson.

Barney, J., Ketchen, D., and Wright, M. (2011). The future of resource- based theory: Revitalization or decline? Journal of Management, 37(5), 1299-1315.

Bastos, W. and Levy, S.J. (2012). A history of the concept of branding: practice and theory. Journal of Historical Research in Marketing, 4(3), pp.347-368.

Bello, D.C. and Gilliland, D.I. (1997). The effect of output controls, process controls, and flexibility on export channel performance. Journal of Marketing, pp.22-38.

Beverland, M., Napoli, J. and Lindgreen, A. (2007). Industrial Global Brand Leadership: A Capabilities View. Industrial Marketing Management. Vol. 36. Issue 8, 1082-1093

Boulding, W., Lee, E., and Staelin, R. (1994). Mastering the mix: does advertising, promotion and sales force activities lead to differentiation? Journal of Marketing Research. Vol. 31. No. 2 pp. 159-72.

Bryman, A. (2006). Integrating quantitative and qualitative research: how is it done? Qualitative research. SAGE: London. Vol. 6(1) 97-113.

Cadogan, J.W. (2012). International marketing, strategic orientations and business success: Reflections on the path ahead. International Marketing Review, 29(4), pp.340-348. 
Cadogan, J.W., Kuivalainen, O. and Sundqvist, S. (2009). Export market-oriented behavior and export performance: quadratic and moderating effects under differing degrees of market dynamism and internationalization. Journal of International Marketing, 17(4), pp.71-89.

Capraro, A., and Srivastava, R. (1997). Has the influence of financial performance on reputation measures been overstated? Corporate Reputation Review, 1(1), 86-93.

Cavusgil, S. and Zou, S. (1994). Marketing Strategy-Performance Relationship: An Investigation of the Empirical Link in Export Market Ventures; Journal of Marketing Vol. 58, No. 1 (Jan., 1994), pp. 1-21.

Chabowski, B., R., Samiee, S. and Hult, G, T., M. (2013). A bibliometric analysis of the global branding literature and a research agenda: Journal of International Business Studies (2013) 44, $622-634$.

Chang, Y., Wang, X. and Arnett, D.B. (2018). Enhancing firm performance: The role of brand orientation in business-to-business marketing. Industrial Marketing Management. 72, pp.1725 .

Chen, J., Sousa, C.M., and He, X. (2016). The determinants of export performance: a review of the literature 2006-2014. International Marketing Review, 33(5), pp.626-670.

Coleman, D.A., de Chernatony, L. and Christodoulides, G., (2015). B2B service brand identity and brand performance: An empirical investigation in the UK's B2B IT services sector. European Journal of Marketing, 49(7/8), pp.1139-1162.

Cortez, R.M. and Johnston, W.J., (2017). The future of B2B marketing theory: A historical and prospective analysis. Industrial Marketing Management, 66, pp.90-102

Creswell, J.W. (2009). Research Design: Qualitative, Quantitative, and Mixed Methods Approaches, Thousand Oaks, CA, Sage.

Creswell, J. W., and Plano Clark, V. L. (2017). Designing and Conducting Mixed Methods Research. London: SAGE.

Cretu, A., E. and Brodie, R., J. (2007). The influence of brand image and company reputation where manufacturers market to small firms: A customer value perspective. Industrial Marketing Management, 36 (2) (2007), pp. 230-240

Day, G. S., and Wensley, R. (1988). Assessing advantage: A framework for diagnosing competitive superiority. Journal of Marketing, 52 (2), 1-20.

Deshpande, R. (1983). "Paradigms lost": On Theory and Method in Research in Marketing. Journal of Marketing, Vol. 47, No. 4 (Autumn, 1983), pp. 101-110.

DeVellis, R. F. (2003). Scale development: theory and applications (2nd ed.). Newbury Park: Sage Publications.

Dhanaraj, C and Beamish, P. (2003). A Resource-Based Approach to the Study of Export Performance. Journal of Small Business Management: Volume 41, Issue 3, pages 242-261.

Dotzel, T. and Shankar, V., (2019). The Relative Effects of Business-to-Business (vs. Business-to-Consumer) Service Innovations on Firm Value and Firm Risk: An Empirical Analysis. Journal of Marketing, Volume: 83 issue: 5, page(s): 133-152 
Ehrenberg, A.S., Uncles, M.D. and Goodhardt, G.J., (2004). Understanding brand performance measures: using Dirichlet benchmarks. Journal of Business Research, 57(12), pp.1307-1325.

Erdogmus, I.E., Bodur, M. and Yilmaz, C. (2010). International strategies of emerging market firms: Standardization in brand management revisited. European Journal of Marketing, 44(91), pp.1410-1436.

Eriksson, K., Johanson, J., Majkgard, A. and Sharma, D. (1997). Experiential knowledge and cost in the internationalization process. Journal of international business studies, pp.337-360.

Farris, P.W., Bendle, N., Pfeifer, P. and Reibstein, D. (2010). Marketing metrics: The definitive guide to measuring marketing performance. Pearson Education.

Fischer, M. and Himme, A. (2017). The financial brand value chain: How brand investments contribute to the financial health of firms. International Journal of Research in Marketing, 34(1), pp.137-153.

Fornell, C. and Larcker, D.F. (1981). Structural equation models with unobservable variables and measurement error: Algebra and statistics. Journal of Marketing Research, pp.382-388.

Freeman, J., Styles, C. and Lawley, M. (2012). Does firm location make a difference to the export performance of SME's? International Marketing Review, Vol. 29. Issue 1, pp. 88-113

FSB (2016). Federation of Small Businesses - Destination export. The smaller business export landscape. Media Centre publication.

Gerbing, D.W. and Anderson, J.C. (1988). An updated paradigm for scale development incorporating unidimensionality and its assessment. Journal of Marketing Research, 186-192.

Gilligan, C. and Wilson, R. (2009). Strategic Marketing Planning. Great Britain: Macmillan.

Glassdoor.com (2018). "Brand manager jobs", available at: https://www.glassdoor.co.uk/Job/brand-manager-jobs-SRCH_KO0,13.htm \{Accessed June, 2018)

Glynn, M., S. (2012). Primer in B2B brand-building strategies with a reader practicum Journal of Business Research, 65 (5) pp. 666-675

Glynn, M., S. and Woodside., A. G. (2009). Advances in Business Marketing and Purchasing Volume 15: Business-To-Business Brand Management: Theory, Research and executive case study exercises. Emerald Group Publishing (UK)

Golder, P. (2000). Historical method in marketing research with new evidence on long-term market share stability. Journal of Marketing Research, 37(2), 156-172.

Gomez-Mejia, Luis R. (1988). The Role of Human Resources Strategy in Export Performance: A Longitudinal Study. Strategic Management Journal, 9 (5), 494-505.

Gov.UK - Department for Business, Energy and Industrial Strategy. (2019). Queens Awards for Enterprise Eligibility criteria. Available from the world wide web: https://www.gov.uk/queens-awards-for-enterprise/eligibility [Accessed 2019].

Gray, C. and Mabey, C. (2005). Management development: Key differences between small and large businesses in Europe. International Small Business Journal, 23, 467-485 
Guitart, I.A., Gonzalez, J. and Stremersch, S. (2018). Advertising non-premium products as if they were premium: The impact of advertising up on advertising elasticity and brand equity. International Journal of Research in Marketing. Vol. 35, Iss 3, pp. 471-489

Hair, J.F. Jr., Black, W.C., Babin, B.J. and Anderson, R.E., (2014). Multivariate Data Analysis. Pearson New International Edition. 7th ed. Prentice-Hall, New Jersey.

Hayes, A.F. (2013). Introduction to mediation, moderation, and conditional process analysis: A regression-based approach. Guilford Publications.

Hair Jr, J.F., Babin, B.J. and Krey, N., (2017). Covariance-based structural equation modeling in the Journal of Advertising: Review and recommendations. Journal of Advertising, 46(1), pp.163-177.

Heise, D.R. (1969). Separating reliability and stability in test-retest correlation. American Sociological Review, pp.93-101.

Hill, S., Ettenson, R. and Tyson, D. (2005). Achieving the ideal brand portfolio. MIT Sloan Management Review, 46(2), p.85.

Himme, A. and Fischer, M. (2014). Drivers of the cost of capital: the joint role of non-financial metrics. International Journal of Research in Marketing, 31(2), pp.224-238.

Homburg, C. Klarmann, M. and Schmitt, J. (2010). Brand awareness in Business Markets: When is it related to firm performance? International Journal of Research in Marketing. 27(3) pp. 201-212

Hultman, M., Katsikeas, C.S. and Robson, M.J., (2011). Export promotion strategy and performance: the role of international experience. Journal of International Marketing, 19(4), pp.17-39.

Iankova, S., Davies, I., Archer-Brown, C., Marder, B. and Yau, A., (2018). A comparison of social media marketing between B2B, B2C and mixed business models. Industrial Marketing Management.

Inskip, I. (2004). Corporate branding for small to medium-sized businesses - A missed opportunity or an indulgence? Journal of Brand Management, 11(5), pp.358 - 365.

Jaworski, B.J. and Kohli, A.K. (1993). "Market orientation: antecedents and consequences", Journal of Marketing, Vol. 57 No. 7, pp. 53-70.

Josephson, B.W., Johnson, J.L. and Mariadoss, B.J., (2016). Strategic marketing ambidexterity: Antecedents and financial consequences. Journal of the Academy of Marketing Science, 44(4), pp.539-554.

Kaleka, A. (2002). Resources and capabilities driving competitive advantage in export markets: guidelines for industrial exporters: Industrial Marketing Management, Volume 31, Issue 3, 15 April 2002, pp. 273-283

Kaleka, A. and Morgan, N.A. (2017). How marketing capabilities and current performance drive strategic intentions in international markets. Industrial Marketing Management.

Kapferer, J.N. (2012). The new strategic brand management: Advanced insights and strategic thinking. Kogan page publishers. 
Katsikeas, C.S., Leonidou, L.C. and Morgan, N.A. (2000). Firm-level export performance assessment: review, evaluation, and development. Journal of the Academy of Marketing Science, 28(4), pp.493-511.

Katsikeas, C.S., Morgan, N.A., Leonidou, L.C. and Hult, T.M. (2016). Assessing Performance Outcomes in Marketing. Journal of Marketing. Vol 80. 1-20

Kaynak, E. and Kuan, W.K.Y. (1993). Environment, strategy, structure, and performance in the context of export activity: an empirical study of Taiwanese manufacturing firms. Journal of Business Research, 27(1), pp.33-49.

Keller, K.L. (2013). Strategic Brand Management: Building, Measuring, and Managing Brand Equity. Global Ed. 4th Edition. Prentice Hall, Essex, UK.

Keller, K.L. (2015). Designing and implementing brand architecture strategies Journal of Brand Management (2015) 21, 702-715.

Keller, K.L. and Lehmann, D.R. (2006). Brands and Branding: Research findings and future priorities. Marketing Science. Vol. 25. No. 6. Pp740-759.

Kohli, A.K. and Jaworski, B.J. (1990). Market orientation: the construct, research propositions, and managerial implications. The Journal of Marketing, pp.1-18.

Kotler, P. and Pfoertsch, W. (2006). B2B Brand Management. Springer.

Kotler, P. and Pfoertsch, W. (2007). Being known or being one of many: the need for brand management for business-to- business (B2B) companies. Journal of Business and Industrial Marketing, Vol. 22 Issue 6 pp. 357 - 362.

Kozlenkova, I., V., Samaha, S. A., and Palmatier, R. W. (2014). Resource-based theory in marketing. Journal of the Academy of Marketing Science. 42: 1-21.

Kuhn, K., Alpert, F and Pope, N. (2008). An application of Keller's brand equity model in a B2B context, Qualitative Market Research: An International Journal, Vol. 11 Issue: 1, 40-58.

Lee, J., Park, S.Y., Baek, I. and Lee, C.S. (2008). The impact of the brand management system on brand performance in B-B and B-C environments. Industrial Marketing Management, 37(7), pp.848-855.

Leek, S. and Christodoulides, G., 2011. A literature review and future agenda for B2B branding: Challenges of branding in a B2B context. Industrial Marketing Management, 40(6), pp.830-837.

Leek, S. and Christodoulides, G., (2012). A framework of brand value in B2B markets: The contributing role of functional and emotional components. Industrial Marketing Management, 4l(1), pp.106-114.

Leonidou, L.C., Barnes, B.R., Spyropoulou, S. and Katsikeas, C.S. (2010). Assessing the contribution of leading mainstream marketing journals to the international marketing discipline. International Marketing Review, 27(5), pp.491-518.

Leonidou, L.C., Katsikeas, C.S. and Samiee, S. (2002). "Marketing strategy determinants of export performance: a meta-analysis", Journal of Business Research, Vol. 55 No. 1, pp. 51-67. 
Lilien, G.L. (2016). The B2B knowledge gap. International Journal of Research in Marketing, 33(3), pp.543-556.

Lilien, G.L. and Grewal, R. (2012). Handbook on Business to Business Marketing. Edward Elgar Publishing.

Madden, T.J., Fehle, F. and Fournier, S. (2006). Brands matter: An empirical demonstration of the creation of shareholder value through branding. Journal of the Academy of Marketing Science, 34(2), pp.224-235.

Maheswaran, D. (1994). Country of origin as a stereotype: Effects of consumer expertise and attribute strength on product evaluations. Journal of Consumer Research, 21(2), pp.354-365.

Makadok R. (2001). Toward a synthesis of the resource-based and dynamic capability views of rent creation. Strategic Management Journal 22: 387-401.

Malhotra, N. K. (2010). Marketing Research an applied orientation. Global Edition, Sixth Edition. Pearson Education Ltd. New Jersey, NY., USA.

Merrilees, B., Rundle-Thiele, S. and Lye, A. (2011). Marketing capabilities: Antecedents and implications for B2B SME performance: Industrial Marketing Management. Volume 40, Issue 3. April 2011, Pages 368-375.

Merrilees, B., Wallace, E., Buil, I., de Chernatony, L. and Guest, D. (2013). Introduction: thought leadership in brand management. Journal of Business Research. 66. 145-147.

Michaelidou, N., Siamagka, N.T. and Christodoulides, G. (2011). Usage, barriers and measurement of social media marketing: An exploratory investigation of small and medium B2B brands. Industrial Marketing Management, 40(7), pp.1153-1159.

Miles, M.B. and Huberman, M., (1994). Qualitative data analysis: An expanded sourcebook. sage.

Moenaert, R.K., and Souder, W.E. (1990). An analysis of the use of extrafunctional information by R\&D and marketing personnel: Review and model. Journal of Product Innovation Management, 7(2), 213-219.

Mohan, M., Brown, B., Sichtmann, C. and Schoefer, K. (2018). Perceived globalness and localness in B2B brands: A co-branding perspective. Industrial Marketing Management. (72)

Montgomery, D.B., Moore, M.C. and Urbany, J.E., (2005). Reasoning about competitive reactions: Evidence from executives. Marketing Science, 24(1), pp.138-149.

Morgan, N.A., 2012. Marketing and business performance. Journal of the Academy of Marketing Science, 40(1), pp.102-119.

Morgan, N., Feng, H. and Whitler, K. (2018). Marketing Capabilities in International Marketing. Journal of International Marketing. Vol. 26, No. 1. pp 61-95

Morgan, N.A., Kaleka, A., and Katsikeas, C.S. (2004). Antecedents of export venture performance: A theoretical model and empirical assessment. Journal of Marketing, 68 (1) 90108. 
Morgan, N.A., Katsikeas, C.S. and Vorhies, D.W. (2012). Export Marketing Strategy Implementation, export marketing capabilities, and export venture performance. Journal of the Academy of Marketing Science. 40:271-289.

Morgan, N.A. and Rego, L.L. (2009). Brand portfolio strategy and firm performance. Journal of Marketing, 73(1), pp.59-74.

Morgan, N.A. and Slotegraaf, R.J. (2012). Marketing Capabilities for B2B firms. In: Lilien, G., L. and Grewal, R. Handbook on Business to Business Marketing: Edward Elgar Publishing p 90-108.

Morgan, N.A., Slotegraaf, R.J and Vorhies, D.W. (2009). Linking marketing capabilities with profit growth. International Journal of Research in Marketing 26. 284-293.

Morgan, N.A., Zou, S., Vorhies, D.W. and Katsikeas, C.S. (2003). Experiential and informational knowledge, architectural marketing capabilities and the adaptive performance of export ventures: a cross-national study, Decision Sciences, Vol. 34 No. 2, pp. 287-322.

Morse, J.M. (2016). Mixed method design: Principles and procedures. Routledge.

Mudambi, S. (2002). Branding Importance in business-to-business markets Three Buyer clusters. Industrial Marketing Management. 31. 525-533.

Murray, J.Y., Gao, G.Y. and Kotabe, M. (2011). Market orientation and performance of export ventures: the process through marketing capabilities and competitive advantages. Journal of the Academy of Marketing Science, 39(2), pp.252-269.

Nakata, C. and Huang, Y. (2005). Progress and promise: the last decade of international marketing research. Journal of Business Research, 58(5), pp.611-618.

Namiki N. (1994). A taxonomic analysis of export marketing strategy: an exploratory study of US exporters of electronic products. Journal of Global Marketing. 1994;8(1):27 - 50.

Narver, J.C. and Slater, S.F. (1990). The effect of a market orientation on business profitability. The Journal of Marketing, pp.20-35.

Nguyen, H.T., Zhang, Y. and Calantone, R.J. (2018). Brand portfolio coherence: Scale development and empirical demonstration. International Journal of Research in Marketing, 35(1), pp.60-80.

Nunnally, J.C. (1978). Psychometric Theory. (2nd Edit.) McGraw-Hill. Hillsdale, NJ.

Nyadzayo, M.W., Matanda, M.J. and Ewing, M.T. (2016). Franchisee-based brand equity: The role of brand relationship quality and brand citizenship behavior. Industrial Marketing Management, 52, pp.163-174.

Oliveira, J.S. and Cadogan, J.W. (2018). A multilevel perspective to the study of export venture performance. International Marketing Review, 35(1), pp.186-199.

Oliveira, J.S., Cadogan, J.W. and Souchon, A. (2012). Level of analysis in export performance research, International Marketing Review, Vol. 29 No. 1, pp. 114-127.

O'Cass, A. and Ngo, L.V. (2007). Balancing external adaptation and internal effectiveness: Achieving better brand performance. Journal of Business Research, 60(1), pp.11-20. 
O'Cass, A., and Ngo, L.V. (2012). Creating superior customer value for B2B firms through supplier firm capabilities. Industrial Marketing Management, 41, 125-135.

Pallant, J. (2013). SPSS Survival Manual: A step by step guide to data analysis, $5^{\text {th }}$ Ed., Open University Press, New York.

Piercy, N.F. and Morgan, N.A. (1994). The marketing planning process: behavioral problems compared to analytical techniques in explaining marketing plan credibility. Journal of Business Research, 29(3), pp.167-178.

Podsakoff, P.M., MacKenzie, S.B., Lee, J.Y. and Podsakoff, N.P. (2003). Common method biases in behavioral research: a critical review of the literature and recommended remedies. Journal of Applied Psychology, 88(5), p.879.

Pratt, M. (2009). From the editors: For the lack of a boilerplate: Tips on writing up and reviewing qualitative research. Academy of Management. Vol 52. No. 5. 856-862.

Reimann, M., Schilke, O. and Thomas, J.S. (2010). Toward an understanding of industry commoditization: Its nature and role in evolving marketing competition. International Journal of Research in Marketing, 27(2), pp.188-197.

Rosenbaum-Elliott, R., Percy, L. and Pervan, S. (2011). Strategic brand management. $2^{\text {nd }}$ Edition. Oxford University Press, USA.

Saldana, J. (2013). The Coding Manual for Qualitative Researchers. Sage Publications (UK).

Santos-Vijande, M. L. Del Río-Lanza A. B. Suárez-Álvarez L. and Díaz-Martín, A. M. (2013). The brand management system and service firm competitiveness. Journal of Business Research. Volume 66, Issue 2, February 2013, Pages 148-157.

Seyedghorban, Z., Matanda, M.J. and LaPlaca, P. (2016). Advancing theory and knowledge in the business-to-business branding literature. Journal of Business Research, 69(8), pp.26642677.

Shocker, A. D., and Weitz, B. (1988). A perspective on brand equity principles and issues (Report No. 91-124). Cambridge, MA: Marketing Science Institute.

Slotegraaf, R.J. and Dickson, P.R. (2004). The paradox of a marketing planning capability. Journal of the Academy of Marketing Science, 32(4), pp.371-385.

Sousa, C. Martinez-Lopez, J. and Coelho, F. (2008). the determinants of export performance: A review of the research in the literature between 1998 and 2005. International Journal of Management Review Volume 10, Issue 4, pages 343-374, December 2008.

Spector, P. E. (1992). A consideration of the validity and meaning of self-report measures of job conditions. International Review of Industrial and Organizational Psychology, 7(1), 123151.

Spradley, J.P. (1979). The ethnographic interview. Fort Worth, TX: Harcourt Brace Jovanovich.

Spyropoulou, S., Skarmeas, D. and Katsikeas, C.S. (2010). The role of corporate image in business-to-business export ventures: A resource-based approach. Industrial Marketing Management, 39(5), pp.752-760. 
Spyropoulou, S., Skarmeas, D. and Katsikeas, C.S. (2011). An examination of branding advantage in export venture: European Journal of Marketing, Vol. 45, No. 6, pp. 910-935.

Srivastava, R., Shervani, T. and Fahey, L. (1998). Market-based assets and shareholder value: A framework for analysis. Journal of Marketing, 62(1), 2-18.

Stewart, D. (2009). The role of method: Some parting thoughts from a departing editor. Journal of the Academy of Marketing Science, 37(4), 381-383.

Swani, K., Brown, B.P. and Mudambi, S.M., (2019). The untapped potential of B2B advertising: A literature review and future agenda. Industrial Marketing Management.

Tashakkori, A. and Teddlie, C. (2003). SAGE Handbook of mixed methods in social and behavioral research. Thousand Oak, CA: Sage.

Torres, A., Bijmolt, T.H., Tribó, J.A. and Verhoef, P. (2012). Generating global brand equity through corporate social responsibility to key stakeholders. International Journal of Research in Marketing, 29(1), pp.13-24.

Ulaga, W. and Eggert, A. (2006). Value-based differentiation in business relationships: Gaining and sustaining key supplier status. Journal of Marketing, 70(1), pp.119-136.

Vorhies, D.W. and Morgan, N.A. (2003). A configuration theory assessment of marketing organization fit with business strategy and its relationship with marketing performance. Journal of Marketing, 67(1), pp.100-115.

Vorhies, D.W. and Morgan, N.A. (2005). Benchmarking marketing capabilities for sustainable competitive advantage. Journal of Marketing. 69(1), 80-94.

Vorhies, D.W., Orr, L.M. and Bush, V.D. (2011). Improving customer-focused marketing capabilities and firm financial performance via marketing exploration and exploitation. Journal of the Academy of Marketing Science, 39(5), pp.736-756.

Wang, C.L. and Hao, A.W. (2018). Advancing theoretical and strategic development of branding in industrial marketing. Industrial Marketing Management 72 (1-3)

Weerawardena, J. and O'Cass, A. (2004). Exploring the characteristics of the market driven firms and antecedents to sustained competitive advantage. Industrial Marketing Management, $33,419-428$.

Wernerfelt, B. (1984). A resource-based view of the firm. Strategic Management Journal, 5(2): 171-180.

Whitelock, J. and Fastoso, F. (2007). Understanding international branding: Defining the domain and reviewing the literature. International Marketing Review, 24(3): 252-270.

Wiersema, F. (2013). The B2B agenda: The current state of B2B marketing and a look ahead. Industrial Marketing Management 42: 470-488.

Wise, R. and Zednickova, J. (2009). The rise and rise of the B2B brand. Journal of Business Strategy, 30(1), pp.4-13.

Wong, H. and Merrilees, B. (2007). Multiple roles for branding in international Marketing. International Marketing Review. Vol. 24. No. 4. pp384-408 
Wong, H. and Merrilees, B. (2008). The performance benefits of being brand orientated Journal of Product and Brand Management, 17 (6) (2008), pp. 372-383

Worm, S. and Srivastava, R.K. (2014). Impact of component supplier branding on profitability. International Journal of Research in Marketing, 31(4), pp.409-424.

WTO, World Trade Organisation. (2014) - WTO Annual Report 2018.

Zablah, A.R., Brown, B.P. and Donthu, N. (2010). The relative importance of brands in modified rebuy purchase situations. International Journal of Research in Marketing, 27(3), pp.248-260.

Zou, S., Fang, E. and Zhao, S. (2003). The effect of export marketing capabilities on export performance: an investigation of Chinese exporters, Journal of International Marketing, Vol. 11 No. 4, pp. 32-55. 
Figure 1 - Conceptual Framework.

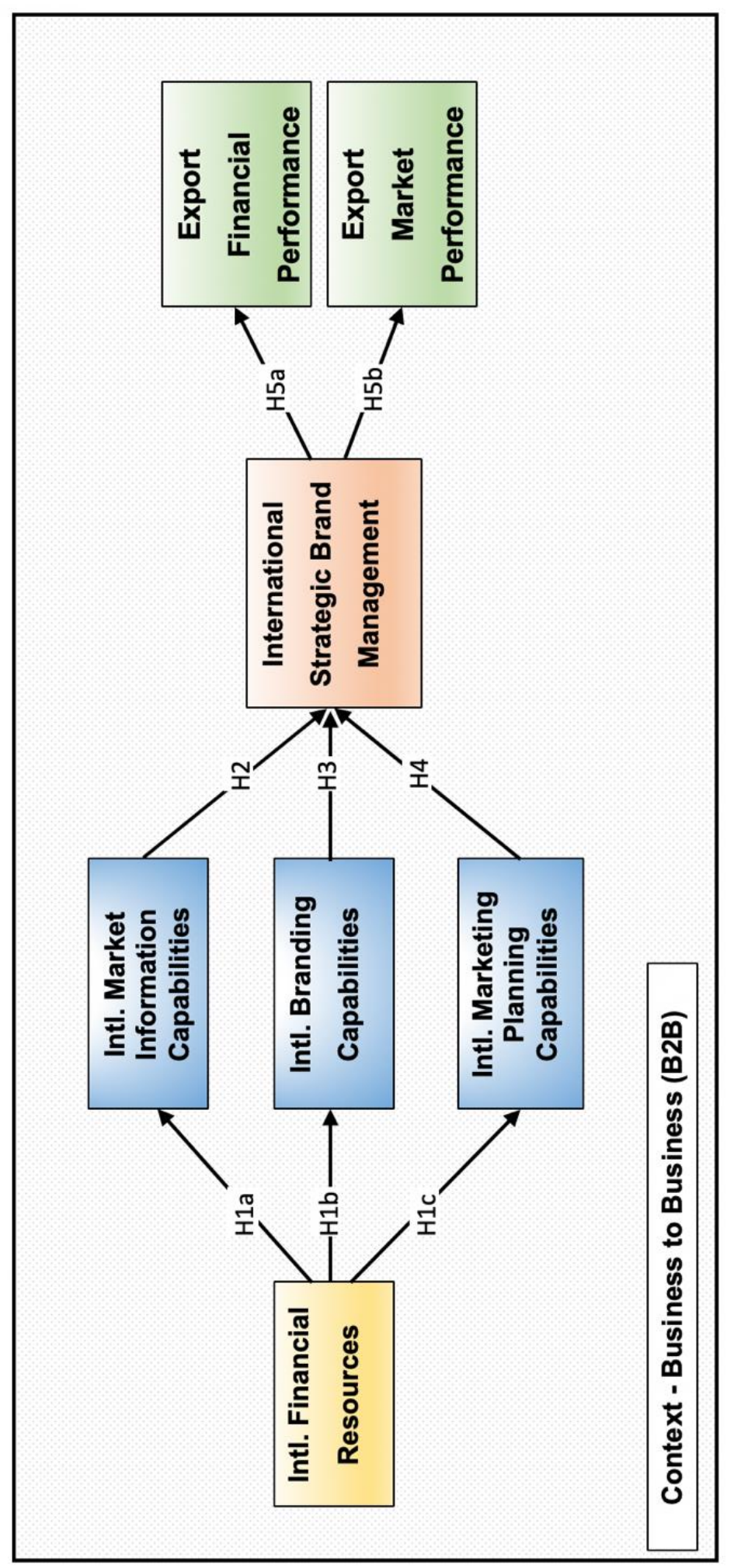


Table 1 - Characteristics of the Qualitative Study Participating Firms and Interviewees.

\begin{tabular}{|c|c|c|c|c|c|c|c|c|}
\hline $\begin{array}{c}\text { Respon } \\
\text { dent }\end{array}$ & Main Industry & $\begin{array}{l}\text { Position } \\
\text { in Firm }\end{array}$ & $\begin{array}{c}\text { Held } \\
\text { position } \\
\text { (Years) }\end{array}$ & Employees & $\begin{array}{l}\text { Turnover } \\
£ \text { (million) }\end{array}$ & $\begin{array}{c}\text { Years } \\
\text { exporting }\end{array}$ & $\begin{array}{c}\text { Number } \\
\text { countries } \\
\text { export }\end{array}$ & $\begin{array}{l}\text { \% sales } \\
\text { exports }\end{array}$ \\
\hline $\begin{array}{l}\text { R1 } \\
\text { R2 }\end{array}$ & $\begin{array}{c}\text { Metals } \\
\text { Industrial }\end{array}$ & $\begin{array}{l}\text { MD } \\
\text { EM }\end{array}$ & $\begin{array}{l}15 \\
9.5\end{array}$ & $\begin{array}{c}100 \\
75\end{array}$ & $\begin{array}{c}7.5 \\
17.1\end{array}$ & $\begin{array}{l}20 \\
22\end{array}$ & $\begin{array}{l}23 \\
37\end{array}$ & $\begin{array}{l}65 \% \\
20 \%\end{array}$ \\
\hline R3 & Auto Accessories & MD & 10 & 3 & 0.5 & 10 & 30 & $70 \%$ \\
\hline R4 & Industrial Doors & MD & 20 & 12 & 13 & 20 & 35 & $60 \%$ \\
\hline R5 & Manufacturing & CEO & 2 & 170 & 25 & 20 & 6 & $10 \%$ \\
\hline R6 & Manufacturing & MD & 4 & 42 & 4 & 17 & 25 & $27 \%$ \\
\hline R7 & Manufacturing & SMD & 3 & 95 & 18 & 7 & 10 & $9 \%$ \\
\hline R8 & Textile & EM & 10 & 140 & 24 & 55 & 60 & $85 \%$ \\
\hline R9 & Textile & MD & 29 & 13 & 1 & 29 & 17 & $60 \%$ \\
\hline $\mathrm{R} 10$ & Textile & MD & 7 & 27 & 1.5 & 50 & 10 & $35 \%$ \\
\hline R11 & Industrial carpets & MD & 2 & 12 & 1.2 & 40 & 7 & $25 \%$ \\
\hline $\mathrm{R} 12$ & Beverage & CEO & 2 & 3 & 0.2 & 2 & 6 & $30 \%$ \\
\hline $\mathrm{R} 13$ & Beverage & MD & 7 & 24 & 5.5 & 20 & 45 & $85 \%$ \\
\hline $\mathrm{R} 14$ & Technology & CEO & 9 & 67 & 6 & 7 & 47 & $97 \%$ \\
\hline $\mathrm{R} 15$ & Technology & $\mathrm{MD}$ & 3 & 5 & 0.5 & 2.5 & 6 & $75 \%$ \\
\hline R16 & Technology & MD & 2.5 & 18 & 0.5 & 3 & 8 & $60 \%$ \\
\hline R17 & Electronics & SMD & 6 & 37 & 3 & 15 & 25 & $14 \%$ \\
\hline R18 & Electronics & $\mathrm{MD}$ & 34 & 25 & 0.5 & 30 & 15 & $80 \%$ \\
\hline R19 & Oil \& Gas & SMD & 3.5 & 105 & 13.5 & 21 & 40 & $50 \%$ \\
\hline $\mathrm{R} 20$ & Oil \& Gas & CEO & 7 & 300 & 40.5 & 15 & 25 & $50 \%$ \\
\hline $\mathrm{R} 21$ & Oil \& Gas & CEO & 7 & 27 & 10 & 4 & 15 & $95 \%$ \\
\hline $\mathrm{R} 22$ & Packaging & BDM & 2 & 7 & 0.25 & 1 & 2 & $90 \%$ \\
\hline $\mathrm{R} 23$ & Packaging & CD & 6 & 55 & 10 & 6 & 35 & $10 \%$ \\
\hline R24 & Engineering & $\mathrm{CD}$ & 2 & 200 & 35 & 60 & 68 & $30 \%$ \\
\hline $\mathrm{R} 25$ & Food & EM & 2 & 8 & 0.13 & 1 & 5 & $5 \%$ \\
\hline $\mathrm{R} 26$ & Food & EM & 5 & 250 & 24 & 19 & 20 & $10 \%$ \\
\hline $\mathrm{R} 27$ & Food & MD & 20 & 140 & 15 & 20 & 18 & $6 \%$ \\
\hline $\mathrm{R} 28$ & Food & SMD & 4 & 74 & 6.5 & 20 & 5 & $1 \%$ \\
\hline $\mathrm{R} 29$ & Paper & $\mathrm{COO}$ & 6 & 25 & 30 & 12 & 48 & $100 \%$ \\
\hline $\mathrm{R} 30$ & Scientific & CEO & 8 & 10 & 2 & 8 & 9 & $85 \%$ \\
\hline R31 & Plastics & $\mathrm{MD}$ & 10 & 8 & 0.6 & 16 & 4 & $2 \%$ \\
\hline R32 & Medical device & $\mathrm{MD}$ & 22 & 50 & 6.7 & 29 & 70 & $65 \%$ \\
\hline R33 & Wind Energy & SMD & 3 & 17 & 5 & 5 & 8 & $90 \%$ \\
\hline R34 & Defence & $\mathrm{MD}$ & 15 & 43 & 4 & 8 & 5 & $70 \%$ \\
\hline
\end{tabular}


Table 2 - Characteristics of the Quantitative Study Sample.

\begin{tabular}{|c|c|c|c|c|c|}
\hline Goods / Services & (n) & $(\%)$ & \% Turnover from Exports & (n) & $(\%)$ \\
\hline Goods & 102 & $49 \%$ & $0-25$ & 27 & $13 \%$ \\
\hline Services & 43 & $21 \%$ & $26-50$ & 36 & $17 \%$ \\
\hline Goods \& Services & 63 & $30 \%$ & $51-75$ & 47 & $23 \%$ \\
\hline \multirow[t]{2}{*}{ Total } & 208 & $100 \%$ & $76-100$ & 98 & $47 \%$ \\
\hline & & & Total & 208 & $100 \%$ \\
\hline Number of Employees & (n) & $(\%)$ & Number of Years Exporting & (n) & $(\%)$ \\
\hline $1-10$ & 21 & $10 \%$ & $1-5$ & 16 & $8 \%$ \\
\hline $11-50$ & 86 & $41 \%$ & $6-10$ & 49 & $23 \%$ \\
\hline $51-250$ & 72 & $35 \%$ & $11-25$ & 83 & $40 \%$ \\
\hline $251-500$ & 12 & $6 \%$ & $26-50$ & 46 & $22 \%$ \\
\hline more than 500 & 17 & $8 \%$ & more than 50 & 14 & $7 \%$ \\
\hline Total & 208 & $100 \%$ & Total & 208 & $100 \%$ \\
\hline Annual Turnover & (n) & $(\%)$ & Number of Export Markets & (n) & $(\%)$ \\
\hline $0-500,000$ & 1 & $0 \%$ & $1-10$ & 43 & $21 \%$ \\
\hline $501,000-1,000,000$ & 6 & $3 \%$ & $11-25$ & 58 & $28 \%$ \\
\hline $1,000,000-5,000,000$ & 69 & $33 \%$ & $26-50$ & 47 & $23 \%$ \\
\hline $5,000,0001-10,000,000$ & 45 & $22 \%$ & $51-100$ & 36 & $17 \%$ \\
\hline $10,000,001-25,000,000$ & 39 & $19 \%$ & more than 100 & 24 & $11 \%$ \\
\hline $25,000,001-50,000,000$ & 26 & $12 \%$ & Total & 208 & $100 \%$ \\
\hline Above 50 million & 22 & $11 \%$ & & & \\
\hline Total & 208 & $100 \%$ & & & \\
\hline
\end{tabular}


Table 3 - Exploratory Factor Analysis (EFA) of International B2B Branding Capabilities.

\begin{tabular}{|l|c|}
\hline \multicolumn{1}{|c|}{ Items } & Factor Loading \\
\hline $\begin{array}{l}\text { Our company utilises available resources to present a simple brand } \\
\text { meaning for our international customers }\end{array}$ & 0.718 \\
\hline Our company uses branding as an operational tool & 0.786 \\
\hline $\begin{array}{l}\text { Our company is able to communicate a consistent brand meaning to } \\
\text { our international customers }\end{array}$ & 0.833 \\
\hline Our company treats our brand as an asset & 0.811 \\
\hline Our staff understand and support our brand meaning and values & 0.648 \\
\hline $\begin{array}{l}\text { Our company uses branding to reduce uncertainty for buyers } \\
\text { within the transaction process }\end{array}$ & 0.727 \\
\hline
\end{tabular}


Table 4 - Constructs Items Factor Loadings Mean SD Skewness Kurtosis.

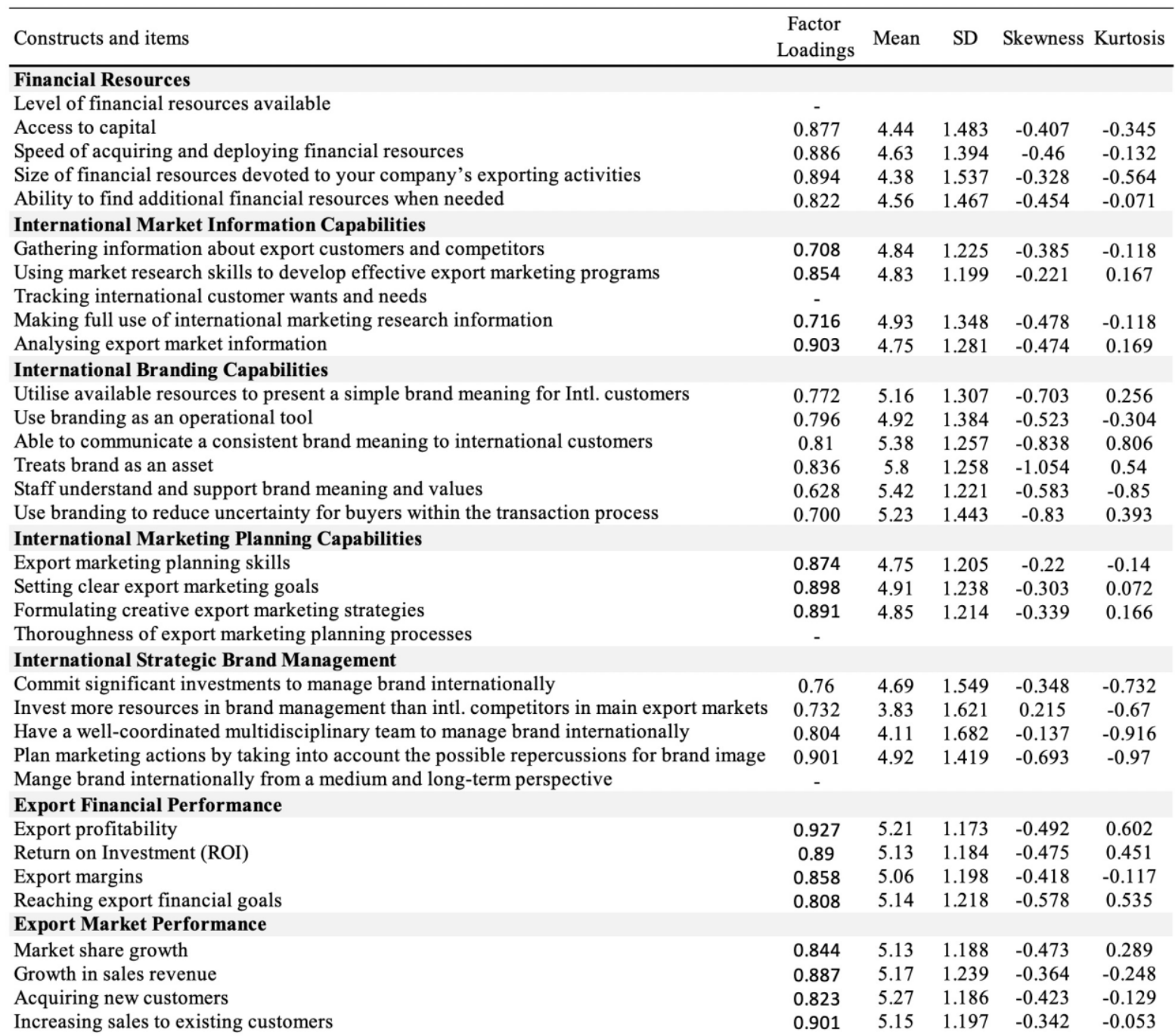


Table 5 - Measurement Model-Construct Reliability (CR), Average Variance Extracted (AVE), Model Fit and Correlation Matrix.

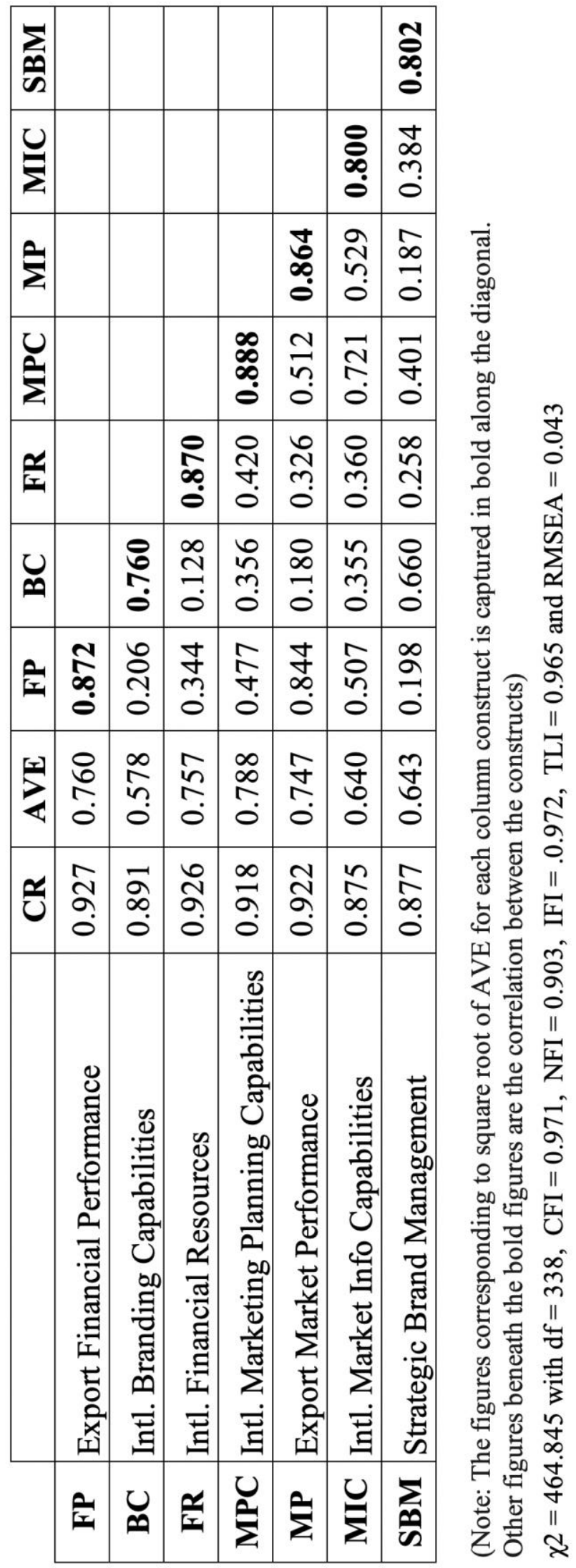


Table 6 - Hypothesis Results.

\begin{tabular}{|c|c|c|c|c|c|c|c|}
\hline \multicolumn{4}{|c|}{ Hypthesised Link } & \multirow{2}{*}{$\frac{\beta}{0.39}$} & \multirow{2}{*}{$\frac{t \text {-value }}{6.104}$} & \multirow{2}{*}{$\frac{\text { Sig. }}{* * *}$} & \multirow{2}{*}{$\frac{\text { Supported? }}{\checkmark}$} \\
\hline H1 (a) & Financial Resources & $\rightarrow$ & $\begin{array}{l}\text { International Market } \\
\text { Information Capabilities }\end{array}$ & & & & \\
\hline H1 (b) & Financial Resources & $\rightarrow$ & $\begin{array}{l}\text { International Branding } \\
\text { Capabilities }\end{array}$ & 0.14 & 2.169 & $* *$ & $\checkmark$ \\
\hline $\mathrm{H} 1$ (c) & Financial Resources & $\rightarrow$ & $\begin{array}{l}\text { International Marketing } \\
\text { Planning Capabilities }\end{array}$ & 0.45 & 7.273 & $* * *$ & $\checkmark$ \\
\hline $\mathrm{H} 2$ & $\begin{array}{l}\text { International Market } \\
\text { Information Capabilities }\end{array}$ & $\rightarrow$ & $\begin{array}{l}\text { International Strategic } \\
\text { Brand Management }\end{array}$ & 0.04 & 0.618 & & $\mathbf{x}$ \\
\hline H3 & $\begin{array}{l}\text { International Branding } \\
\text { Capabilities }\end{array}$ & $\rightarrow$ & $\begin{array}{l}\text { International Strategic } \\
\text { Brand Management }\end{array}$ & 0.7 & 17.67 & $* * *$ & $\checkmark$ \\
\hline $\mathrm{H} 4$ & $\begin{array}{l}\text { International Marketing } \\
\text { Planning Capabilities }\end{array}$ & $\rightarrow$ & $\begin{array}{l}\text { International Strategic } \\
\text { Brand Management }\end{array}$ & 0.22 & 3.819 & $* * *$ & $\checkmark$ \\
\hline H5 (a) & $\begin{array}{l}\text { International Strategic } \\
\text { Brand Management }\end{array}$ & $\rightarrow$ & $\begin{array}{l}\text { Export Financial } \\
\text { Performance }\end{array}$ & 0.26 & 3.904 & $* * *$ & $\checkmark$ \\
\hline H5 (b) & $\begin{array}{l}\text { International Strategic } \\
\text { Brand Management }\end{array}$ & $\rightarrow$ & $\begin{array}{l}\text { Export Market } \\
\text { Performance }\end{array}$ & 0.18 & 2.628 & $* * *$ & $\checkmark$ \\
\hline$F p$ & $0.001 ; * * \mathrm{p}<0.05$ & & & & & & \\
\hline
\end{tabular}

